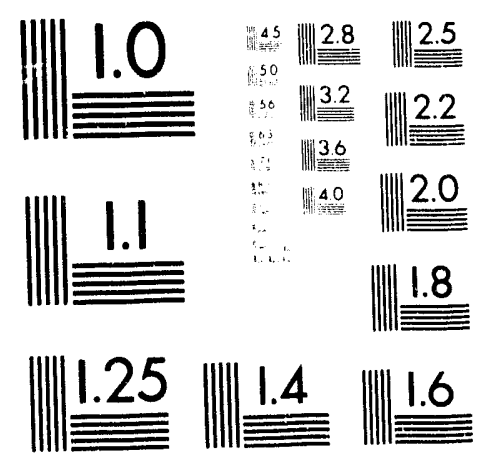



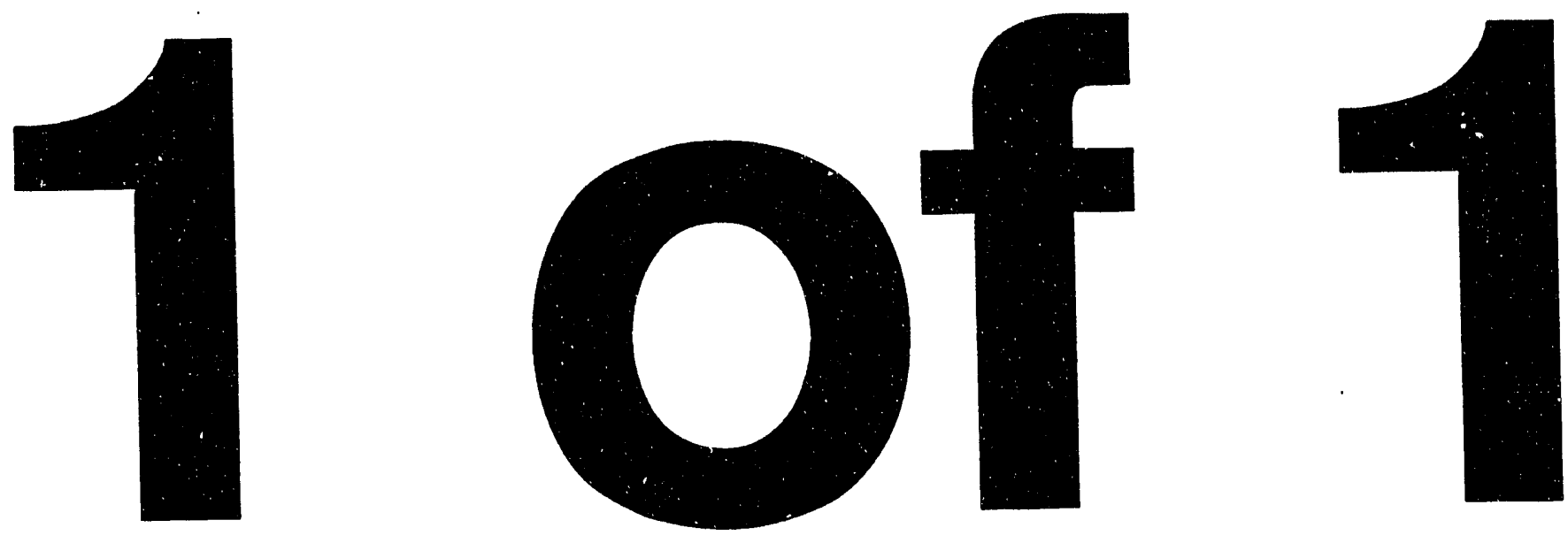


\section{TRANSPORTATION: ENVIRONMENT, ENERGY AND THE ECONOMY}

Leon Petrakis, Chairman Department of Applied Science Brookhaven National Laboratory Upton, NY 11973

January 11,1993

Under Contract No. DE-AC02-76CH00016

U.S. Department of Energy

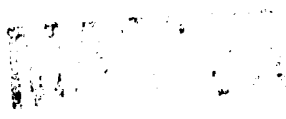




\section{DISCLAIMER}

This report was prepared as an account of work sponsored by an agency of the United States Government. Neither the United States nor any agency thereof, nor any of their employees, nor any of their contractors, subcontractors, or their employees, makes any warranty, express or implied, or assumes any legal liability of responsibility for the accuracy, completeness, or usefulness of any information, apparatus, product, or process disclosed, or represents that its use would not infringe privately owned rights. Reference herein to any specific commercial product, process, or service by trade name, trademark, manufacturer, or otherwise, does not necessarily constitute or imply its endorsement, recommendation, or favoring hy the United States Government or any agency, contractor or subcontractor thereof. The views and opinions of authors expressed herein do not necessarily state or reflect those of the United Siates Government or any agency, contractor or subcontractor thereof. 


\section{ABSTRACT}

Highway related transport has characterized the American Ce tury, but as the universal paradigm for developed and developing nations it has significant and unsustainable implications for the next. 
ABSTRACT $\ldots \ldots \ldots \ldots \ldots \ldots \ldots \ldots \ldots \ldots \ldots \ldots \ldots \ldots \ldots \ldots \ldots \ldots$

EXECUTIVE SUMMARY $\ldots \ldots \ldots \ldots \ldots \ldots \ldots \ldots \ldots \ldots \ldots \ldots$

INTRODUCTION $\ldots \ldots \ldots \ldots \ldots \ldots \ldots \ldots \ldots \ldots \ldots \ldots \ldots \ldots$

TECHNOLOGICAL DEVELOPMENTS AND TRANSPORT MODES $\ldots \ldots \ldots \ldots \ldots$

THE NATIONAL ENERGY STRATEGY AND THE ENERGY

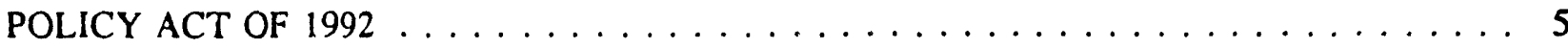

TRANSPORTATION SECTOR ENERGY PROFILE $\ldots \ldots \ldots \ldots \ldots \ldots \ldots$

TRANSPORTATION SECTOR ENVIRONMENTAL PROFILE $\ldots \ldots \ldots \ldots \ldots$

ECONOMY PROFILE AND IMPLICATIONS OF

TRANSPORTATION SECTOR $\ldots \ldots \ldots \ldots \ldots \ldots \ldots \ldots$

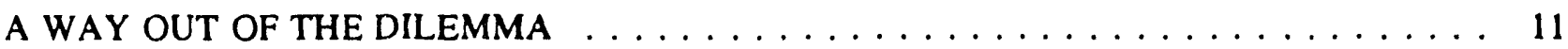

CRITICAL TECHNOLOGIES RESEARCH:

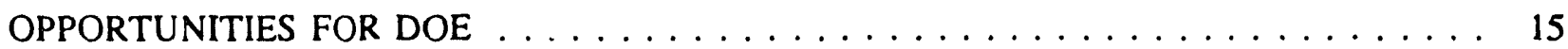

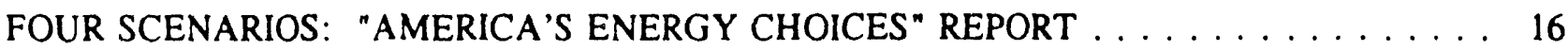

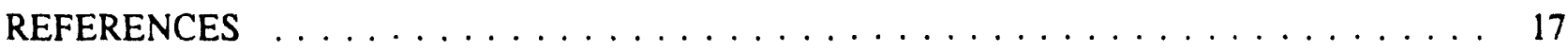

ACKNOWLEDGEMENTS $\ldots \ldots \ldots \ldots \ldots \ldots \ldots \ldots \ldots \ldots \ldots \ldots$

APPENDIX I

A. ENERGY PROFILE $\ldots \ldots \ldots \ldots \ldots \ldots \ldots \ldots \ldots \ldots \ldots \ldots \ldots \ldots \ldots \ldots$ I.A.

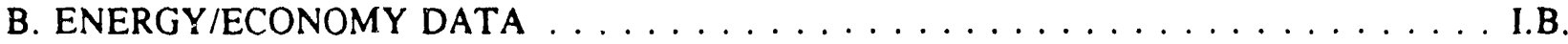

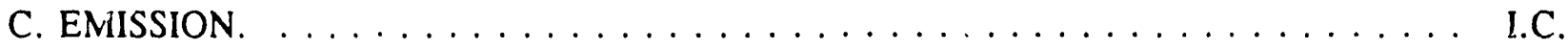

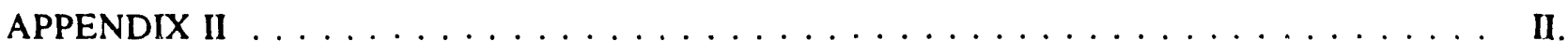




\section{EXECUTIVE SUMMARY}

A California advertisement proclaims homosapiens has become autosapiens.

The automobile has compelling advantages - comfort, convenience and freedom of movement. It also causes serious problems -- congestion, pollution, injuries, and loss of productivity. The Energy Policy Act of 1992 explicitly calls for reducing dependence on imported oil, and the National Energy Strategy (NES) - no environmental extremist document -- laid the foundation for a "more efficient, less vulnerable, and environmentally sustainable energy future." Policies pursued during the Automobile Century have led, Sisyphus-like, to a transportation system that fails the NES criteria; and, staying the course, will not meet them. The war in the Gulf, the instability of the former Soviet Union, the environmental fragility of possible oil bearing regions in the U.S., and the finiteness of the resource only partially define the problem.

\section{The U.S. Transportation Sector}

- is dominated by cars and trucks - the least energy efficient modes;

- consumes over one quarter of the entire energy used -- more oil than the U.S. produces domestically;

- is responsible for a significant fraction of all emissions including greenhouse gases; and

- makes an inordinately small contribution to the Gross Domestic Product (GDP) and employment for the high fraction of energy that the sector consumes.

Technology has determined the evolution of the transportation system from canals to railroads to the automobile. Incremental technological improvements (catalytic converters, reformulated gasoline) have been quite remarkable, but not a solution. Gains made through technical improvements often have been diminished or negated by increases in miles travelled and the population.

Public and private investments historically have been made on the now discredited assumption that economic growth depends on increases in energy use. The Japanese and German economies have lower "energy intensities" (amount of energy needed to produce a unit of GDP). Energy efficiency measures taken after the first energy crisis are credited to a large extent for the growth of the U.S. economy after 1972. Restructuring the transportation sector to be more energy-efficient will create jobs on a sustained basis and provide the added dividends of cleaner environment and lower national security risk.

The first necessary step is an assessment of each mode's true costs, exactly as the Energy Policy Act of 1992 calls for meeting future needs for energy services "at the total lowest costs to the Nation, including environmental costs"; and as the NES advocated that fuel choices must be based on "an improved understanding of total fuel-cycle costs .... including the cost of health and environment impacts." Economists have often dismissed some costs simply as "externalities," thereby (along with hidden subsidies and confusion of costs with benefits) distorting the economic picture and interfering with the free markets. An accurate understanding of costs would facilitate the introduction of the new technologies -- including vehicle, fuel and systems innovations -- that must be the next transportation system. 
In addition we need to:

- allow the prices of the different modes to reflect their true costs; but readjustments must be made gradually to mitigate the hardship of those affected the most; and

- adopt measures that promote the more energy-efficient modes. Provisions of the 1990 Clean Air Act Amendments do that. Incentives to decrease the vehiclemiles travelled; high occupancy vehicle lanes; shifting of subsidies from individual cars to vans and carpools and mass transit; lower mass transit ticket costs at peak hours; teleconferencing; scrappage of older cars; bicycle paths; and synchronized traffic lights provide attractive possibilities.

The passage of the INTERMODAL SURFACE TRANSPORTATION EFFICIENCY ACT of 1991 heralds a departure from the previous focus on highway building. The Act provides direct funding for transit, significant R\&D for MAGLEV and Intelligent Vehicle Highway Systems, and, most importantly, flexibility of transport policies and approaches that address local needs.

Meeting this challenge will require the scientific and technological resources of government, private sector and universities. The National Laboratories ("crown jewels" of American science in the words of Senator Dominici) are repositories of capabilities that can provide the competitive advantage to American industry in the global economy. MAGLEV - potentially a significant next century transport mode - was the result of fundamental studies in magnetism at Brookhaven National Laboratory. However, the prototypes of MAGLEV were built in Japan and Germany. Effective partnerships between National Labs and vigorous private sector R\&D can prevent such occurrences and help move to a new transportation system that increases employment and economic well-being, while lowering the insults to health and environment and the potential threats to national security. 


\section{INTRODUCTION}

The quintessential characteristic of the contemporary transportation system in the industrialized world is road-and highway-related travel. It has also become the paradigm for the developing economies. Homosapiens, in the words of a California advertisement, truly has become autosapiens. Senator D. P. Moynihan(1) in a recent "Letter to New York" discussing the passage of the Intermodal Surface Transportation Efficiency Act of 1991 refers to a GM 1939 press release which exhorted one to visualize the cities of the future. "Just imagine!... Living in New York when it looks like this: What with its buildings overhead of auto roads-aero rooming places atop 200-story buildings -- penthouses amid stars and clouds. Here is a good conception of the ever-climbing-skyward city - the Metropolis of the World - as it will appear in the future." The central feature of the vision of these futuristic cities was the limited access, divided highway. Senator Moynihan attributes the genesis of the Interstate and Defense Highway Act of 1956 (paid for by the Highway Trust Fund) to the thinking exhibited at the 1939 World's Fair, and summarized by the press release quoted. Of course, things have not quite materialized in such a neat and utopian fashion (Fig. 1).

Judging from the themes used by the advertising agencies in promoting the automobile worldwide, most consumers in purchasing an automobile seem to be buying more than personal transportation. The advantages of the automobile are many and significant - comfort, convenience and freedom of movement - and they have played a key role in its being established as the dominant mode of personal transportation. Transport of goods by truck similarly has significant advantages. At the same time the problems associated with this mode are equally significant: Urban and suburban congestion, threat to the environment, safety and the local and global implications are the most obvious. Others, less obvious but equally significant, are the implications of the system for the economy and employment, national security and land use.

In the U.S., the transportation sector consumes over one quarter of the entire energy used, almost in its entirety as petroleum products, and in quantities greater than the total U.S. domestic oil production. The transportation sector is responsible for a significant fraction of all emissions that either prevent U.S. cities from achieving compliance with EPA air quality standards or have serious global change implications. Finally, the GDP (Gross Domestic Product) and employment due to the sector are low and incommensurate with the high fraction of energy that the transportation sector consumes. We examine below this situation in some detail and make recommendations for improvements. 


\section{TECHNOLOGICAL DEVELOPMENTS AND TRANSPORT MODES}

Technology has played the key role in the development of transport modes by increasing the elasticity of substitution among various modes and by shortening the time required to make widely acceptable a particular transport mode. For millenia, the dominant sources of motive power for transport of people and goods were animals and natural sources of wind and water flow. The harnessing of the phenomenon of $\mathrm{com} \mathrm{b}$ u s $\mathrm{tion}$ is the great landmark that transformed radically transport modes. Initially this was achieved through the steam engine, but the truly significant event was the development of the internal combustion engine. Grübler and Nakicenovic(2) have reviewed this matter and they show that technologies have evolved in remarkably similar patterns. Technological breakthroughs proceed in three, well-delineated phases. The first is a slowly developing induction period, during which there may be important technological developments, but the penetration of the new technologies into the economy is slow. This is followed by a second phase which is characterized by the rapid diffusion into the economic system of the technological changes resulting in wide acceptance of the new technology. Finally, there is a third mature period at which marginal improvements and also a definite saturation take place. Eventually new technological breakthroughs appear that go through similar cycles and displace the older technologies. Canals showed such a pattern of slow development, rapid diffusion and eventually a maturity period. Canals were replaced by railroads, and eventually the highway-mode of transport made significant gains on rail transport. Currently airplane travel is still expanding (Fig. 2).

An additional important factor contributing to the dominance of the road- and highway-related transport was the parallel breakthroughs in petroleum processing. More specifically, these breakthroughs involved the development of materials with the ability to "crack" the larger molecules of petroleum and to control the addition or removal of hydrogen in the chemical moities that constitute gasoline, diesel and jet fuels. These materials -- silica aluminas, zeolites and aluminum-phosphates, often modified through the addition of small quantities of carefully dispersed noble metals, such as platinum, or bimetallics, such as rhenium and platinum -- have unique catalytic properties that carefully balance and control on the molecular level complex often competing reactions that result in fuels of remarkable predictability and quality. These breakthroughs have entailed great progress in understanding fundamental chemical phenomena acidity, hydrogenation/dehydrogenation reactions - and their technological harnessing in immense quantities through the use of often cheap abundant materials that operate efficiently for long periods and in extremely hostile environments of high temperature and pressure and in the presence of molecular poisons. These fuel-related developments interestingly enough also followed similar patterns as the transportation modes themselves. 


\section{IV.A THE NATIONAL ENERGY STRATEGY AND THE ENERGY POLICY ACT QF 1992}

Almost two decades after the first "energy crisis" the U.S. has found itself without a long range and comprehensive energy policy. In July 1989, President George Bush directed the Department of Energy to come up with a National Energy Strategy (NES)(3) that would provide a road map as to how the U.S. expected to produce and use energy in the future. The NES was released in February of 1991 after significant inputs from many experts, agencies and interested groups, and also after many revisions and much controversy.

Flawed and much criticized, nevertheless the NES specifically laid the foundation for a "MORE EFFICIENT, LESS VULNERABLE, and ENVIRONMENTALLY SUST.AINABLE energy future, " and clearly established criteria by which the energy future was to be judged, namely: the environment including health and safety, the economy, and national security. Late in 1992 , the "Energy Policy Act of 1992" was approved by the Congress. The Conference Report (4), details the agreement forged by the Home and Senate Conferees on the compromise bill that finally emerged from Congress. The Act emphasizes conservation and energy efficiency as it explicitly states:

"It is the goal of the United States in carrying out energy supply and energy conservation research and development

(1) to strengthen national energy security by reducing dependence on imported oil:

(2) to increase the efficiency of the economy by meeting furure needs for energy services at the lowest total cost to the Nation, including environmental costs, giving comparable consideration to technologies that enhance energy suppl $j^{\prime}$ and technologies that improve the efficiency of energy end uses;

to reduce the air, water, and other environmental impacts (including emissions of greenhouse gases), of energy, production, distribution, transportation, and utilization, through the development of an environmentally sustainable energy system;

to maintain the technological competitiveness of the United States and stimulate economic growth through the development of advanced materials and technologies;

to foster international cooperation by developing international markets for domestically produced sustainable energy tecinnologies, and by transferring environmentally sound, advanced energy systems and technologies to developing countries to promote sustainable development;

(6) to consider the comparative environmental and puhlic health impacts of the energy to be produced or saved by the specific activities;

(7) to consider the obstacles inherent in private industry's development of new energy technologies and steps necessary for establishing or maintaining technological leadership in the area of energy and energy efficiency resource technologies;

to consider the contribution of a given activity on fundamental scientific knowledge. "(4) 
I ne Energy Policy Act in addressing the transportation sector specifically calls for the Department of Energy to conduct a program on "cost effective technologies to reduce demand for oil in the transportation sector for all motor vehicles, including existing vehicles, through increased energy efficiency and the use of alternative fuels. "(5) When the transportation sector is examined in terms of these criteria, it becomes very clear that opportunities exist for improvements in this sector with potentially large impacts on the environment, the economy and national security.

The transport of people in the U.S. is overwhelmingly dominated by the private automobile. In $1986^{(0)}$. the private transport was responsible for 2118 billion passenger-miles while the public transport accounted for merely 24 billion passenger miles. This 90 to 1 ratio of private to public transport contrasts with 8 to 1 for (W.)Germany and 4 to 1 ratio for Japan. The transport of goods is much more balanced in terms of road-to-rail distribution. Actually in the U.S. more ton-miles are accounted for by railroads ( 888 trillion) than by ruad-related means (627 trillion ton-miles). In (W.)Germany and Japan more tonmiles are accounted for by road transport than by rail (1:0.44 and 1:0.1 ratios correspondingly for Germany and Japan).

Clearly then tire problem faced by the U.S. transportation sector is primarily the movement of penple and secondarily the movement of goods. 
The Transportation Sector consumes over one quarter of the total energy used in the U.S. In $1989,(6)$ out of the 81.3 Quads total energy used ( 41.25 million barrels per day oil equivalent), 21.9 Quads (or 11.1 million barrels per day oil equivalent) were for transportation (Table I). The total U.S. oil consumption was 17.2 million barrels per day (34 Quads) $67 \%$ of which (10.8 million barrels per day) went into the transportation sector. The total U.S. gil production was only 9.1 million barrels per day. What matters then is not only that the transportation sector uses a quarter of the total energy, but the nature of the energy as well: $97 \%$ of the energy in transportation was from oil, and the entire U.S. oil production was short by $1.7 \mathrm{million} \mathrm{bbl} / \mathrm{per}$ day of oil in meeting the needs for transportation. Recent further diminution of the U.S. Oil production is exacerbating this situation. Thus, past and potential energy shortages are shortages of liquid fuels that affect primarily the transportation sector. The national security implications of this situation are obvious. The recent war in the Gulf, the expectations that the U.S. will continue to project its presence in the region possibly well into the next century, the instability of the former Soviet Union, the environmental fragility of the possible oil bearing regions in the U.S. (offshore, Artic National Wildlife Refuge) and the very finiteness of the resource and declining production rates provide a good measure of the problem.

The liquid fuel problems of the transportation sector relate primarily to road transport. Nearly three quarters of the transportation sector energy (72.2\%) (Fig. 3) is for automobiles and trucks, with air and rail accounting for $20.7 \%$ and the remainder for construction, farming and the military.(6) Fig. 3 also shows $(6,7)$ the energy intensities [as Btu per passenger-mile, and Btu per vehicle-mile! and the actual energy use in Quads for the different modes. The personal truck and automobile are the most energy-intensive modes of passenger transport, even on a Btu/passenger-mile basis with the load factors shown. On a Btu/passenger-mile basis, rail and buses have lower energy intensities, inter-city buses considerably lower while walking and bicycling are the least energy intensive modes. These energy intensity figures of merit, coupled with distribution of energy use among the various modes, indicate what short-term steps, as well as longer term structural changes, might be pursued to bring about desirable improvements in the transportation sector.

The transport of freight presents an analogous picture. Trucks are the largest energy consuming mode for transport of freight, using 2.42 Quads (Fig. 4). Yet, on a Btu/ton-mile basis for 1988, the energy intensity of this popular mode of transport was 8-10 times higher than the energy intensities for water-borne commerce and railroads.

Since the transport of people is dominated by the private automobile, it is useful to state the fuel economy of the automobile population and the trends over the years (Fig. 5). The 1978 automobile population in the U.S. had an average efficiency of 13.8 miles per gallon, which was significantly lower than those of Japan (19.8) and of Germany (21.4). By 1988 the U.S. automobile population showed a dramatic improvement to 17.8 miles per gallon, but still it lagged behind those of Japan and Germany which also had registered some improvements (21.8 and 22.0 miles per gallon correspondingly for Japan and Germany). 


\section{IV.C TRANSPORTATION SECTOR ENVIRONMENTAL PROFILE}

The environmental implications of the transportation sector are many, wide-ranging and significant. The implications are particularly severe if one considers the entire cycle for fuels production, conversion and use. Their impact is local, regional and global, and encompass the entire biosphere -- atmosphere, land and the oceans. Emissions of concern with local, regional and global impacts include unburned or altered fossil fuels, products of combustion and heavy metals. $\mathrm{CO}, \mathrm{CO}_{2}, \mathrm{NO}_{\mathrm{x}}, \mathrm{CFC}$ 's and heavy metals are environmental hazards resulting from current transportation fuel use. Too much ozone in the lower troposphere is of concern as are the reduced levels of ozone in the stratosphere. In addition to these well recognized and often quoted hazards, there are other ways in which the environment is burdened by the transportation sector. These include noise, congestion, land use, solid wastes, discharges into waterways, injuries and bodily harm and short and long-term health effects. Finally, one needs to mention explicitly the possible effects on global climate change since the transportation sector involves several key greenhouse gases -- $\mathrm{CO}_{2}, \mathrm{NO}_{\mathrm{x}}$ and CFC's.

The immensity of the problem perhaps may be appreciated best by pointing out that one liter of gasoline produces 0.6 kilos of carbon or approximately 2.5 kilos of $\mathrm{CO}_{2}$. For the U.S. the contribution of the various pollutants due to the transportation sector are shown in Table II.(6) The transportation sector accounts for $67 \%$ of the total $\mathrm{CO}, 41 \%$ of $\mathrm{NO}_{\mathrm{x}}$ and $32.8 \%$ of the volatile organics that determine the ozone. 


\section{IV.D ECONOMY PROFILE AND IMPLICATIONS OF TRANSPORTATION SECTOR}

A causal relationship between energy consumption and economic growth has been a widely held position both in the free as well as the planned economics. An important Office of Technology Assessment Study(8) points out that "economic growth was assumed to be linked to increases in energy use and public and private investments were made that rested on that assumption." Although there continues to be some diversity of opuion, the current consensus is that there is a decoupling between energy consumption and "economic growth." The conclusion of the OTA study is unequivocal as it states "economic growth is not necessarily contingent on using more energy." In fact, Fig. 6 shows the trends in Energy use, GDP and the "Energy Intensity of the Economy," (which is define's as "the amount of energy required to produce a unit of GDP") from 1952 to 1988 . Between 1950 and 1972 GDP and energy use grew in parallel by $3.5 \%$ per year, and thus the energy intensity remained flat. Between 1972 and 1985 GDP growth was $2.5 \%$ per year, while energy use increased by $0.3 \%$ per year resulting in the "Energy Intensity" falling by $2.4 \%$ per year. After 1985 , energy use increased by $3.9 \%$ and GDP grew by $4.1 \%$, again the Energy Intensity remaining flat. The trend of level energy use was broken in 1986 due to strong economic growth and a shift in the mix of consumption towards more energy-intensive products. The energy efficiency improvements between 1972-1985 means that the 1985 economy would have used 15 Quads more energy if these improvements in energy intensity had not been achieved. Structural shifts in the economy also are credited as having contributed to the energy savings.

The transportation sector in the U.S. consumes over a quarter of the total energy in the U.S. (Table III and Fig. 7). This fraction has shown small variations since before the first "energy crisis" of 1973. What is striking is that the investment of this very large fraction of energy produced only $6.5 \%$ of the total GNP and only $5.0 \%$ of the jobs in 1989 . (The U.S. employment figures(9) for the transportation sector are from the publication of the U.S. Burea: of Labor statistics "Employment and Wage, Annual Averages" and include all economic activities under SIC Codes $4000-49000$. The Transportation Gross National Product figures are from Oak Ridge National Laboratory Report 5198, Jan. 1991. They include motor vehicle and other transportation equipment manufacturing; railroad transportation; local and interurban passenger transit, trucking and warehousing; water transportation; transportation by air; pipelines, except natural gas; transportation services; and auto repairs, services and garages). Actually, there has been a small deteriorating trend in the sense that employment in the Transportation Sector has gone down to $5.0 \%$ from $5.9 \%$, and the Transportation Sector GNP has gone down to $6.5 \%$ from $7.6 \%$ between 1977 and 1989 while the energy use has gone from $25 \%$ to $26.9 \%$ in the same period. Clearly, since the national concern is for creation of jobs, the Transportation Sector presents significant possibilities for the invested energy to be used in a manner that would produce more jobs than is currently the case. Thus, it is imperative to move to more energy efficient modes as well as to bring about the required structural changes in this sector.

In addition to the disparity between energy investment in the transportation sector and the resulting low number of jobs/low Transportation Sector GNP, two additional facts need to be noted: a) the Energy Intensity of the Transportation Sector is even lower than that in the overall economy; and b) even though there have been significant improvements in the Energy Intensity of the transportation sector in the U.S. (Figs. 8A, and 8B) (with a decrease of 27\% between 1970 and 1988) the Japanese and the German(W) Transportation Sector energy intensities were lower than in the U.S. and they also showed significant improvements over the same period. This is true 
especially for the Japanese transportation sector. There are demographic, geographical and other factors that make difficult the one-on-one comparisons, but given the fact that at every turn there are comparisons being made between the U.S. and the German and Japanese experiences, it would be very useful to carefully analyze these situations and extract and apply the useful lessons here. The U.S. transportation sector presents possibilities for growth in jobs while minimizing the undesirable current characteristics such as insults to the environment and dependence on foreign oil.

Now, before we leave the examination of the economic aspects of the transportation sector, it may be useful to make some comments or the popular yardstick of economic well being, the GNP. The need for quantitative assessment of human well-being has given rise to numerica: indices that provide the basis of measuring progress and making comparisons over time and across regions. These efforts for quantification use descriptive language, which is as imprecise as it is optimistic ("growth," "development," "standard of living," "goods," etc.) adding to the over simplification of what are really complex issues. As $\mathrm{H}$. Daly $(10)$ points out, human wellbeing is multidimensional encompassing economic, psychological, environmental and healthrelated factors. Yet, often the tendency has been to give primacy and even exclusivity to the economic factor.

GNP or GNP per capita is the most commonly employed numerical index that measures market activity. However, the index itself and its derivatives have been employed to further describe market welfare and even human well-being. Economists often deny the validity of this extension, but the practice is well entrenched, and the ritual of receiving and disseminating the quarterly or annual GNP figures is well known and practiced among politicians, pundits, popular economic writers and lay people. The always hoped-for growth of these numerical indices and their perceived importance as a gauge of human well-being is well established and beyond question.

GNP is a rather recently developed index, when in 1934 the U.S. Department of Commerce began publishing data on the net product of the national economy. The British and Canadians followed with data in 1943, and in 1947 the League of Nations convened a meeting on national income accounting. The rest, as they say, is history. GNP measures money flow from households to business or the equal flow of money from business to households.

This popular and convenient index of market activity has been criticized on several grounds: a) it is used not just as a measure of market activity, but, by extension, as a measure of the health of the economy and beyond as a measure of human well-being; b) in the drive to maximize GNP no distinction is made between costs and benefits, and instead of subtracting costs they are added.

Another view of emissions discussed earlier and their connection to GDP is given by Table III that compares the U.S. with the German and Japanese experiences.(11) The production of emissions in tons per capita as well as per $\$ 1000$ GDP are higher for the U.S. and some cases significantly higher, indicating that there is room in the U.S. experience both to lower the insult to the environment and to enhance the wealth (GDP) production through a more judicious investment of the energy in the transportation sector. A similar situation obtains with the other greenhouse gases. 


\section{A WAY OUT OF THE DILEMMA}

It is clear from this discussion that the policies followed have led to the current unsatisfactory state of the transportation sector. Our overwhelming dependence on the least energy efficient mode - private automobile and the truck for the movement of people and goods, respectively has created a situation that, despite the heavy investment of energy, has potential for significant improvement. The question therefore arises as to what can be done to improve the situation. Before we offer specific suggestions, it will be useful to consider briefly the analysis made by Ehrlich and Holdgren(12) of the total impact that various activities may have on the environment. It is a simple but elegant and compelling framework within which activities such as those of the transportation sector may be viewed and properly understood.

Ehrlich and Holdgren point out that the total impact of a given activity is the product of three factors, i.e.

$$
\text { Total Impact }=(\text { Technology }) \times(\text { Affluence }) \times(\text { Population })
$$

For example, total $\mathrm{NO}_{x}$ emissions from burning fossil fuels in internal combustion engines is the product of

$$
\text { T.1. }=\text { (emissions per vehicle-mile) } \times \text { (vehicle-miles per person }) \times \text { (persons) }
$$

Thus, the $\mathrm{NO}_{\mathrm{x}}$ emissions depend not only on how much $\mathrm{NO}_{\mathrm{x}}$ is emitted for each mile traveled but also by the total number of vehicle-miles being travelled and the number of persons using this kind of transportation. The first factor (emissions per vehicle-mile travelled) is clearly a TECHNOLOGY factor that is being affected by such developments as catalytic converters, clean fuels, tuning of the engine, etc. The second factor (vehicle-miles traveled per person) is an AFFLUENCE factor that reflects the extent of the availability of cars. Finally, increasing population can impact negatively a situation despite possible improvements from technological breakthroughs. In fact, it is possible and even likely that population growth and increasing affluence can diminish or even negate gains made from technological improvements.

Research and development efforts for mitigation of pollution have been focused almost exclusively on incremental technological improvements. Surely the achievements of these R\&D efforts have been quite remarkable. Yet the fact remains that today major urban centers do not meet EPA ambient air quality standards. Gains that have been made through technological improvements (catalytic converters, clean fuels) have been diminished or negated by increases in the miles being travelled and the population. In a recent study at the California Institute of Technology(13) it has been shown that "even complete removal of automobiles from the Los Angeles area would not be sufficient to eliminate the local ozone air quality compliance problem." The calculated spatial distribution of the 1-hr maximum concentration for zero highway motor-vehicle emissions shows significant areas at or above the federal ozone air quality standard of $0.12 \mathrm{ppm}$ (Fig. 9). This of course is due to the fact that emissions from other sources are quite substantial and no improvements in the technology of the automobile would bring about compliance with ozone air quality standards unless other activities were brought into compliance also. 
It might be useful to reconsider the plight of Sisyphus as the necessary actions are being decit for breaking out of the dilemma that has been created with the contemporary transportation s. tem. Also, it might be useful to have in mind the compelling analysis of Ehrlich and Holdgr as the controversy of development vs protection of the environment unfolds. Often the dialogu whether on a local basis or on the North-South scale, deteriorates into two parallel monologut with selective emphasis on the POPULATION OR AFFLUENCE factors and the implicit accep tance of the omnipotence of the technological fix.

The analysis that has been attempted shows that the Transportation Sector is indeed a subject to improvements in terms of greater increased economic productivity and job creation, energy efficiency, lower adverse environmental impact, and national security exposure. Clearly, the issue is very complex and not subject to quick and painless fixes. Improvements can be effected both on a short term basis, and more importantly, on a intermediate and longer term basis. Specifically what can be done?

Our answer is that whatever actions are taken they need to be based on a thorough and accurate assessment of the true costs and benefits involved as called by the Energy Policy Act of 1992. The Act calls "to increase the efficiency of the economy by meeting future needs for energy services at the lowest total cost to the Nation, including environmental costs..." Even the National Energy Strategy - no environmental extremist document -- for example, on the choice of fuels, specifically states that "motivating our technology and resource choices must be an improved understanding of total fuel-cycle costs .... including the cost of health and environment impacts." This approach can be generalized to all components of the transportation sector. Hidden subsidies, confusion of costs with benefits, avoidance of the inevitable pain of changes, burdening the future generations with our convenience and lack of foresight, confusing needs with luxuries and wants, ignoring the finiteness of the resources and the fragility of the environment, sacrificing the longer term to short time gains, all are hindrances to a thorough and accurate assessment of the situation that will continue to prevent us from achieving the benefits that can be hard. We insist on this point, i.e., a thorough and accurate assessment of the available options, for it is critical to the success of the required efforts for change and improvement. For too long, economists have simply defined actual costs as "externalities" and have dismissed them thereby distorting the true economic picture and rendering unworkable the free markets. If indeed we accept the notion that free markets should determine our optimal options, we must internalize these "externalities," calculate the true costs of each option, and then let the free markets be really free.

The National Energy Strategy had pointed out that "existing analytical tools are not capable of doing this \{i.e., the thorough assessments\} with any reasonable precision; however, developing and sharing this capability to make such total fuel-cycle cost assessments is a NES priority." Progress already has been made, and the necessary capability for making such assessments is to some extent already in place in terms of computer models such as MARKAL (from Market Allocation) at Brookhaven National Laboratory. While this computer modeling capability is being fully developed (the effort involved is short term and readily achievable) so that the necessary longer term structural changes necessary can be assessed, short term actions can be taken to start immediately improving the situation. Such actions as the following may be considered. 
1. Pursue the many promising technological developments both for short term improvements and long term innovations. Technological breakthroughs should increase our choices and/or hasten the introduction and acceptance of the improvements in existing or new systems. The possibilities for innovations are many and included to the following:

$\begin{array}{ll}\text { vehicular innovations: } & \begin{array}{l}\text { electric vehicles } \\ \text { fuel cells } \\ \text { gas turbines } \\ \text { power batteries } \\ \text { low heat rejection diesel engine }\end{array} \\ \text { systems innovations: } & \begin{array}{l}\text { high speed rail } \\ \text { magnetic levitation } \\ \text { intelligent vehicles and highways } \\ \text { air traffic control }\end{array} \\ \text { Fuels innovations: } \quad \begin{array}{l}\text { clean fuels } \\ \text { advanced fuels from biomass } \\ \text { hydrogen }\end{array}\end{array}$

2. Undertake measures that will help move the transportation sector towards the desirable restructuring. Here we are presented with many possibilities that would be pursued based on particular community or regional needs as well as measures on a national scale. Based on the analysis for TOTAL IMPACT, incentives to decrease the vehicle-miles travelled could readily be put in place through such measures as increased high occupancy vehicles lanes and shifting of subsidies from individual cars to vans and carpools or mass transit. Since congestion is primarily a commuter phenomenon, such measures as flex time, staggering of working hours, lower mass transit ticket costs at peak hours, all would help to bring short term improvements. Teleconferencing, incentives to accelerate scrappage of older cars, bicycle paths, synchronized traffic lights and Corporate Average Fuel Emissions (CAFE) standards are some measures that should be considered for their obvious environmental and economic effects. The list can be expanded significantly and there is no dearth of suggestions along these lines.

3. Allow the price of the current mix of transportation modes to reflect the true cost of each mode. We know that the current prices of fuels and vehicles do not reflect their true cost (e.g., the fraction of the national defense that goes for securing the oil we import; environmental and health costs that are dismissed as "externalities" and not accounted; and the many subsidies from building of highways to the services provided for dealing with fatalities and injuries and counting them as enhancing the economic welfare of the nation. At this last point, a very interesting and readily employable measure is the suggestion made by $A$. Rosenfeld,(14) Univ. of California, to require car safety stickers in the same manner as with fuel efficiency stickers). On the other hand, we do not know their exact cost. Therefore, readjustments need to be gradual and to be made in a manner that mitigates the hardship resulting from the necessary changes especially with the segments of the society affected the most. 
Congress has recently passed the INTERMODAL SURFACE TRANSPORTATION EFFICIENCY ACT (ISTEA) of 1991. The Act, authorizing the expenditure of $\$ 155$ billion, has been heralded as a radical departure from the almost total focus of the past several decades on highway building. The major share of the expenditures under this Act is still slated for highway related transport (\$121 billion). This includes $\$ 21$ billion for the New Highway System. However, almost $\$ 24$ billion is earmarked for a new program, the Surface Transportation Program (STP); $\$ 32$ billion for direct funding of transit; and significant R\&D for MAGLEV (magnetically levitated trains, $\$ 775$ million) and IVHS (Intelligent Vehicle Highway Systems, \$660 million). More importantly, the Act allows for significant flexihility of transport policies and approaches, as the very title of the Act emphasizes, through the key roles of state and local inputs. Thus the Act recognizes the need to address critical aspects of the overall problem such as congestion and air pollution noncompliance, and allows the states to transfer $50 \%$ of New Highway System funds to the Surface Transportation System. This flexibility is likely to allow the meaningful consideration of both short-term and long-term solutions including High Occupancy Vehicle (HOV) lanes, sjnchronization of traffic lights, transit capital projects, transport planning, and the demonstration projects under the Congested Corridors Program.

This is a very good start on the road to developing a transportation system that retains the advantages of the current system but it also moves us towards a system that overcomes the obvious shortcomings by increasing employment opportunities, lowering the insults to health and environment and lessening the potential threats to national security. 
VI. CRITICAL TEC:INOLQGIES RESEARCH: OPPORTUNITIES FOR DOE

The Office of Energy Research of the Department of Energy convened a Workshop in Berkeley, CA, on May 27-29, 1992, that addressed, inter alia, critical technologies research for the transportation sector. A report on the Workshop was issued in Dec. 1992. (15)

Light vehicles were identified as a prime target for national lab - industry collaboration. Critical technologies identified were:

- Engines and emissions management

- Ceramic gas turbines

- Batteries and fuel cells

- Ultra-capacitors and flywheels (an alternative to batteries

- Material recycle and disposal

- Modernizing the infrastructure (e.g., "smart" highways). 
VII. FQUR SCENARIOS: "AMERICA'S ENERGY CHOICES" REPORT

In 1991, four national organizations undertook a study to address some of the issues raised here. The four organizations were: Alliance to Save Energy, American Council for an Energy-Efficient Economy, National Resources Defense Councils and Union of Concerned Scientists in Consultation with the Fellow Institute.

The study consisted of investigating four different scenarios: a REFERENCE CASE, with current policies and trends; a MARKET CASE that would minimize the cost of energy services; and ENVIRONMENTAL CASE which would account for the environmental costs of energy use; and a CLIMATE STABILIZATION CASE for set targets for reducing $\mathrm{CO}_{2}$ emissions. While continuing current trends would increase energy consumption by $41 \%$ through 2030 , the other three scenarios would reduce energy use, while also reducing air pollution emissions, and bring about significant monetary savings.

Specifically, the transportation sector shows that "energy efficiency can be increased by improving vehicle technology by shifting to more efficient transportation modes, by changing land-use patterns," and by implementing measures that reduce wasteful transfers. "(16) The two figures for this report (Figs. 10 and 10A) summarize the results. 


\section{REFERENCES}

1. D. P. Moynihan, "Letter to New York," Jan. 1992.

2. A. Grübler and N. Nakicenovic, "Evolution of Transport Systems: Past and Future," IIASA, Laxenburg, Austria (1991).

3. "National Energy Strategy," First Edition, 1991/1992, Washington, DC.

4. The Energy Policy Act of 1992, Title XX, Section 2001.

5. Ibid, Section 2027.

6. S. C. Davis and M. D. Morris, "Transportation Energy Data Book," Edition 12, Oak Ridge National Laboratory, Oak Ridge, TN, 1992.

7. D. Gordon, "Steering a New Course, " Union of Concerned Scientists, Cambridge, MA, 1991.

8. Office of Technology Assessment, "Energy Use and the U.S. Eccnomy," Washington, DC, 1990.

9. U.S. Bureau of Labor Statistics, "Employment and Wage, Annual Averages," 1989.

10. H. Daly, "For the Common Good," 1991.

11. Organization for Economic Conperation and Development, "Environmental Indicators," Paris, France, 1991.

12. P. Ehrlich and J. Holdgren, Science, 1971, 171, 1212-1217.

13. G. Cass, California Institute of Technology, private communication.

14. A. Rosenfeld, University of California (Berkeley), private conimunication.

15. "Critical Technologies Research: Opportunities for DOE," National Workshop Report, May 27-29, 1992, Berkeley, CA.

16. "America's Energy Choices: Investing in a Strong Economy and a Clean Environment," Executive Summary, 1991. 


\section{ACKNOWLEDGEMENTS}

Valuable discu

Critical Technsions and various The Tables and ogies Worksh acknowledged, as is the were prepared by $B$. help of M. Hobson who typed the Melucci whose help isted here. 
BNL PERSONNEL

J. Hurst

J. Lee

S. Morris

B. Pierce

M. Rowe

J. Wegrzyn 


\section{NATIONAL LABS/STAFF RESPONDING TO QUESTIONNAIRE}

National Lab

Argonne National Laboratory

Battelle Pacific Northwest Laboratory

Brookhaven National Laboratory

Lawrence Berkeley Laboratory

Los Alamos National Laboratory

National Renewable Energy Laboratory

Oak Ridge Nationai Laboratory

Sandia National Laboratories

Non-National Lab

General Motors

Rockwell International
Staff

L. R. Johnson

J. White

S. Morris

B. Pierce

J. Wegrzyn

D. F. Grether

R. A. Lemons

R. Stokes

D. L. Greene

J. Kelsey

N. Magnani

Staff

J. G. Simon

H. L. Reynolds 


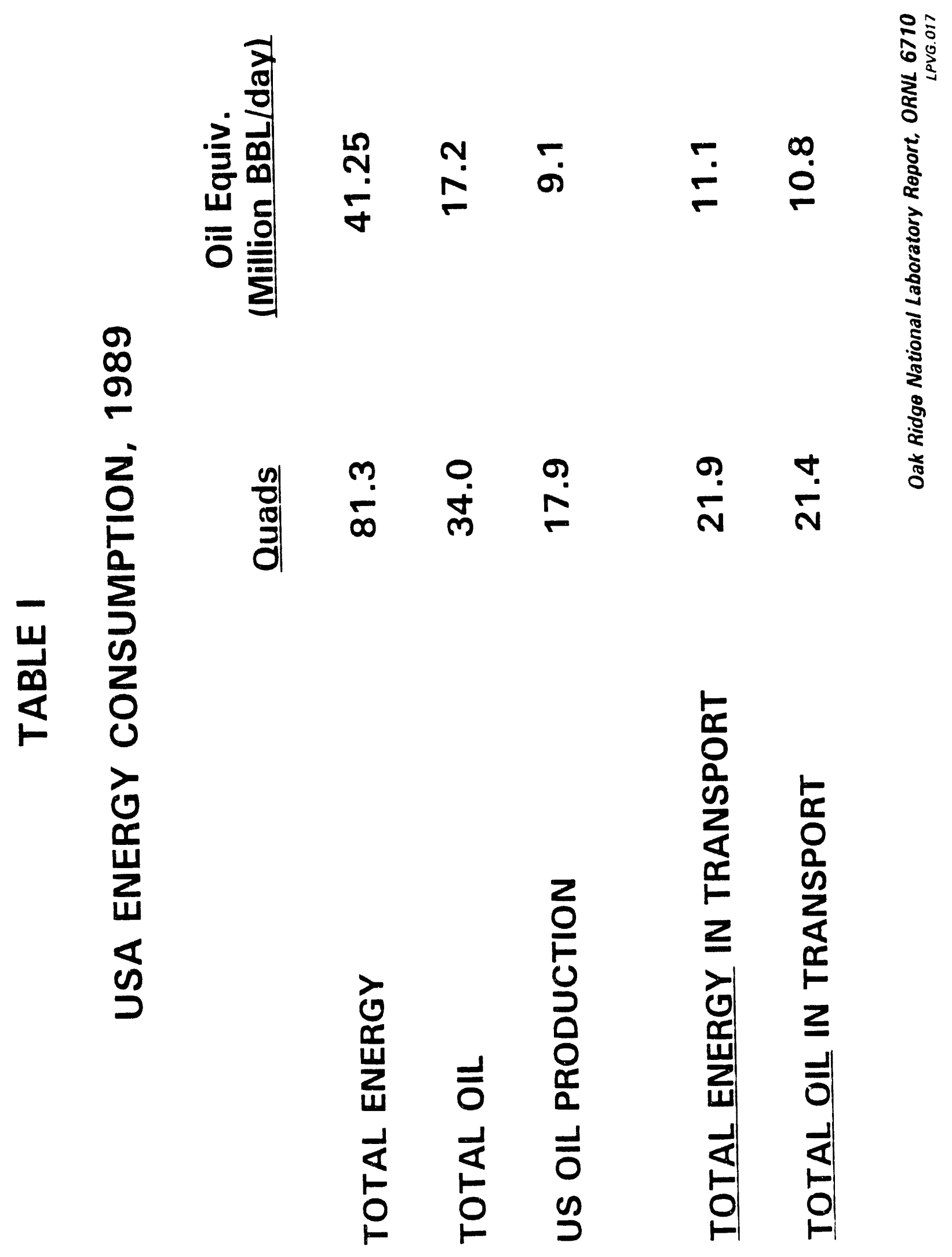




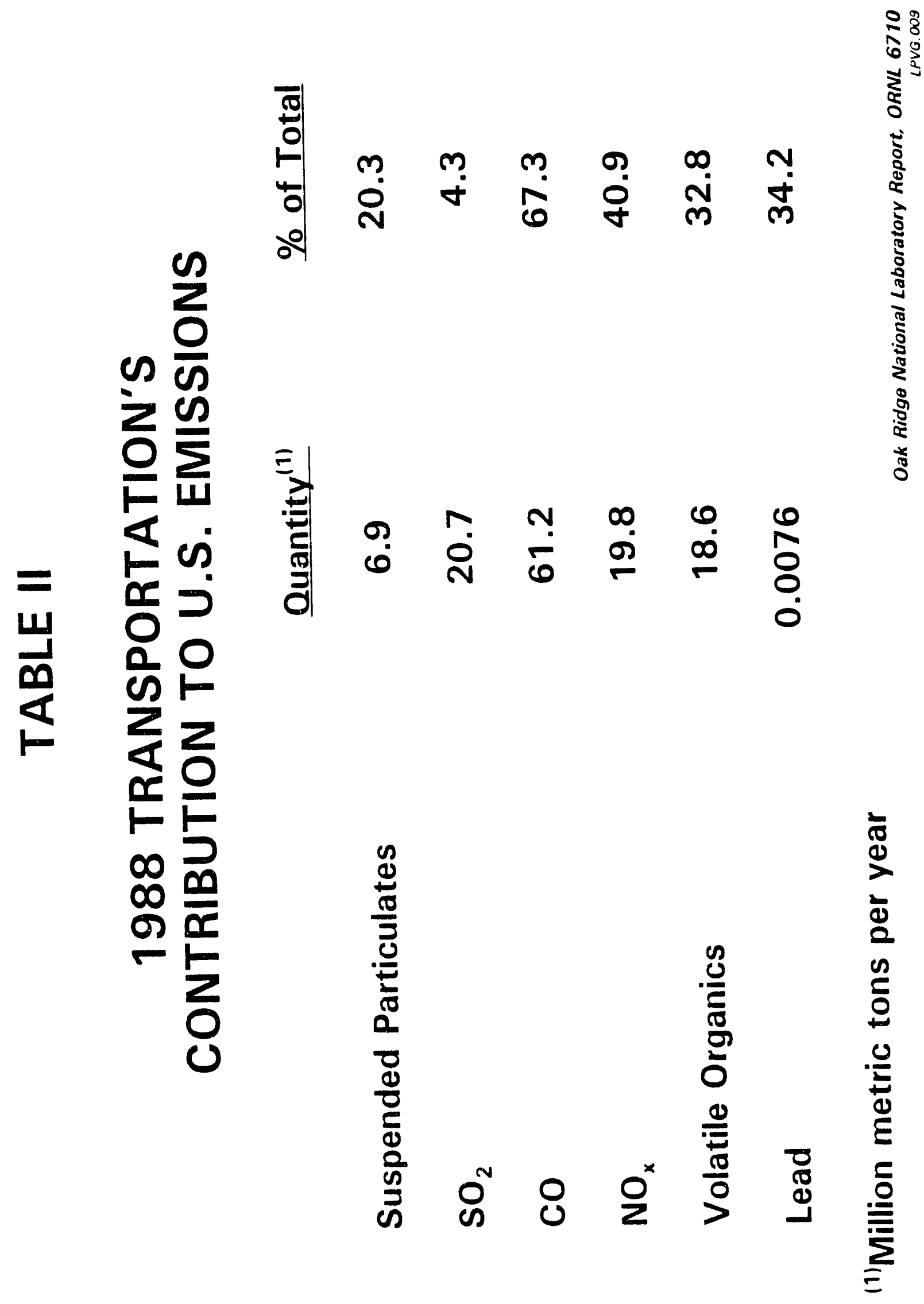



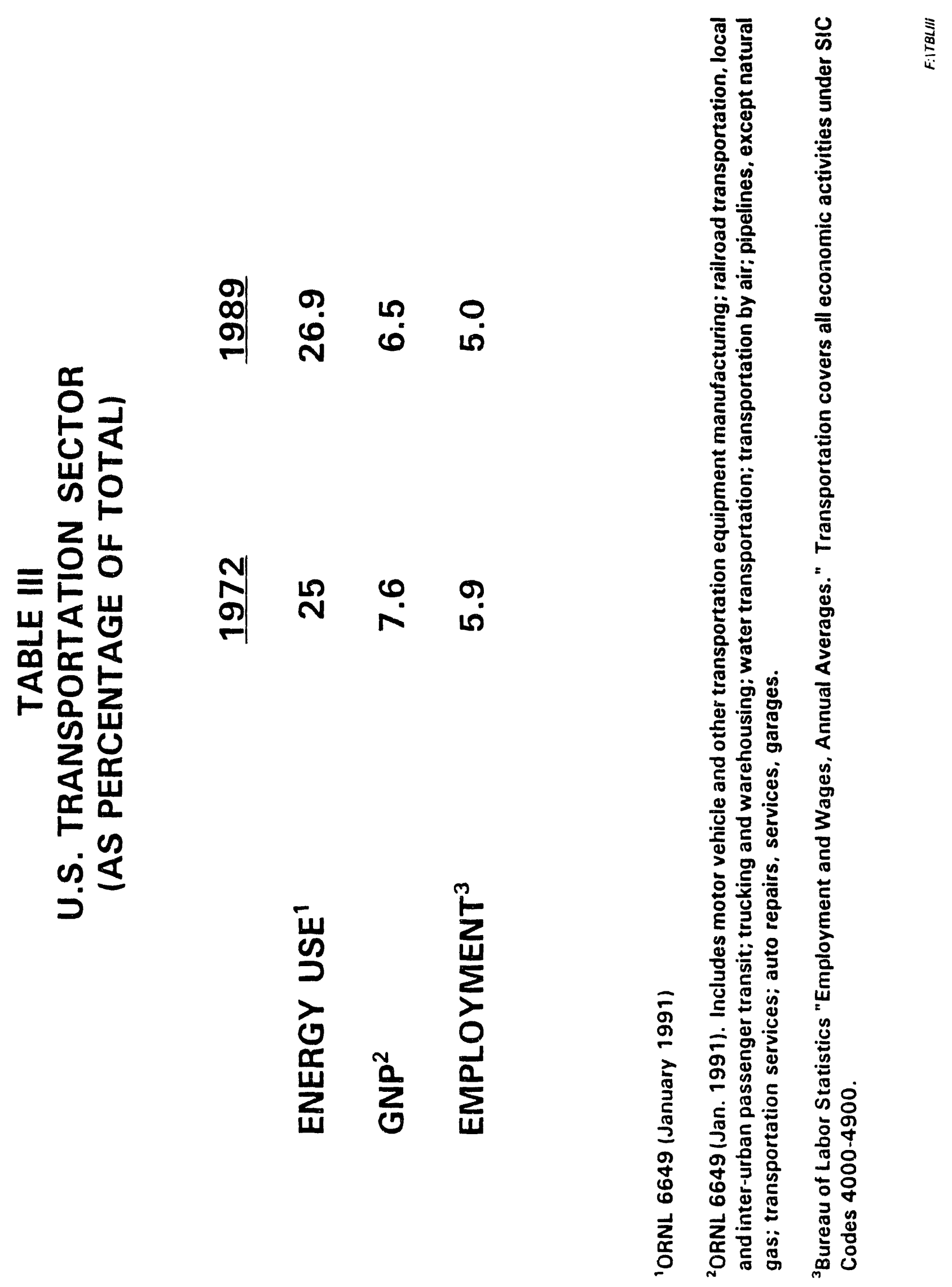


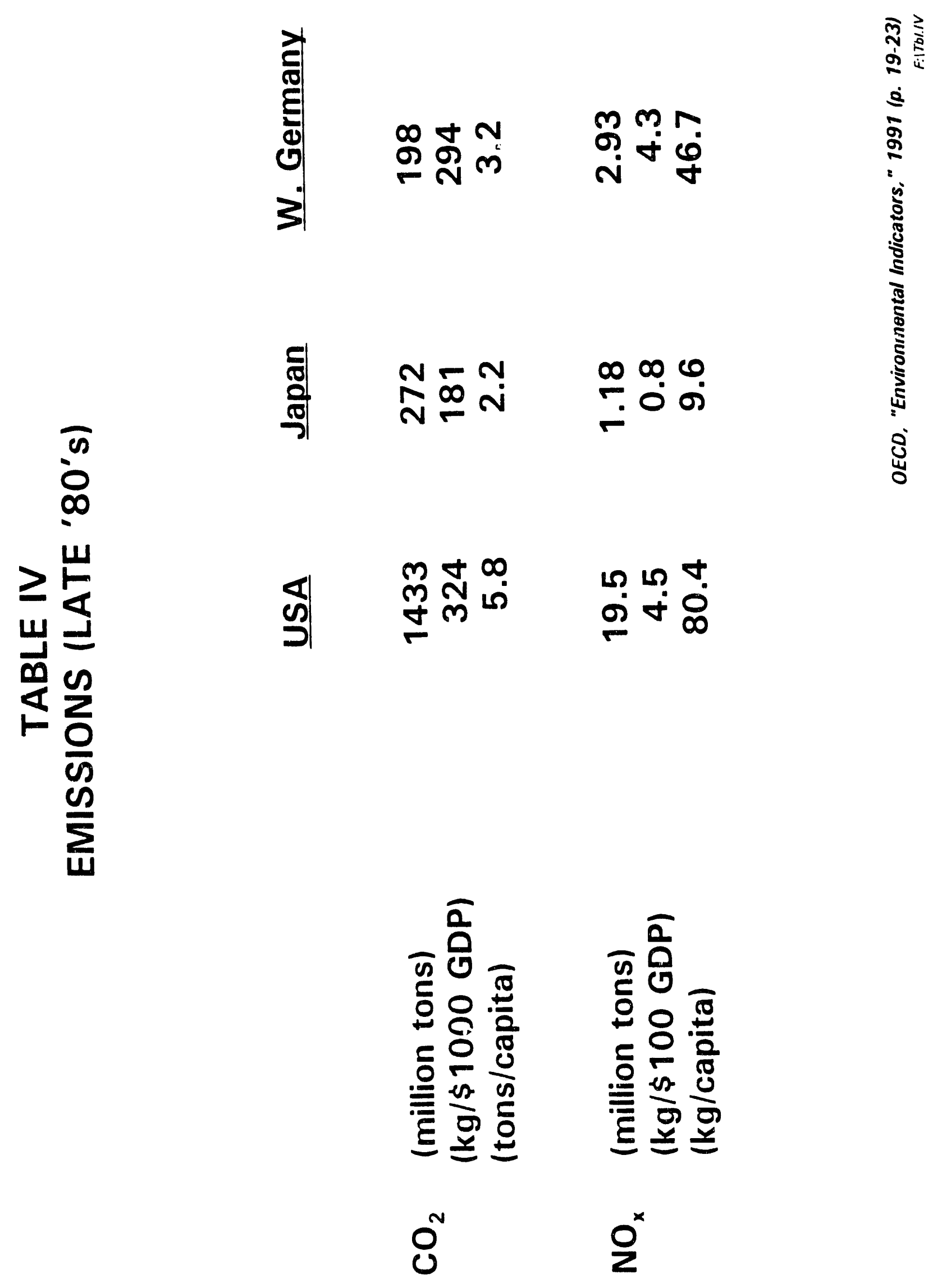




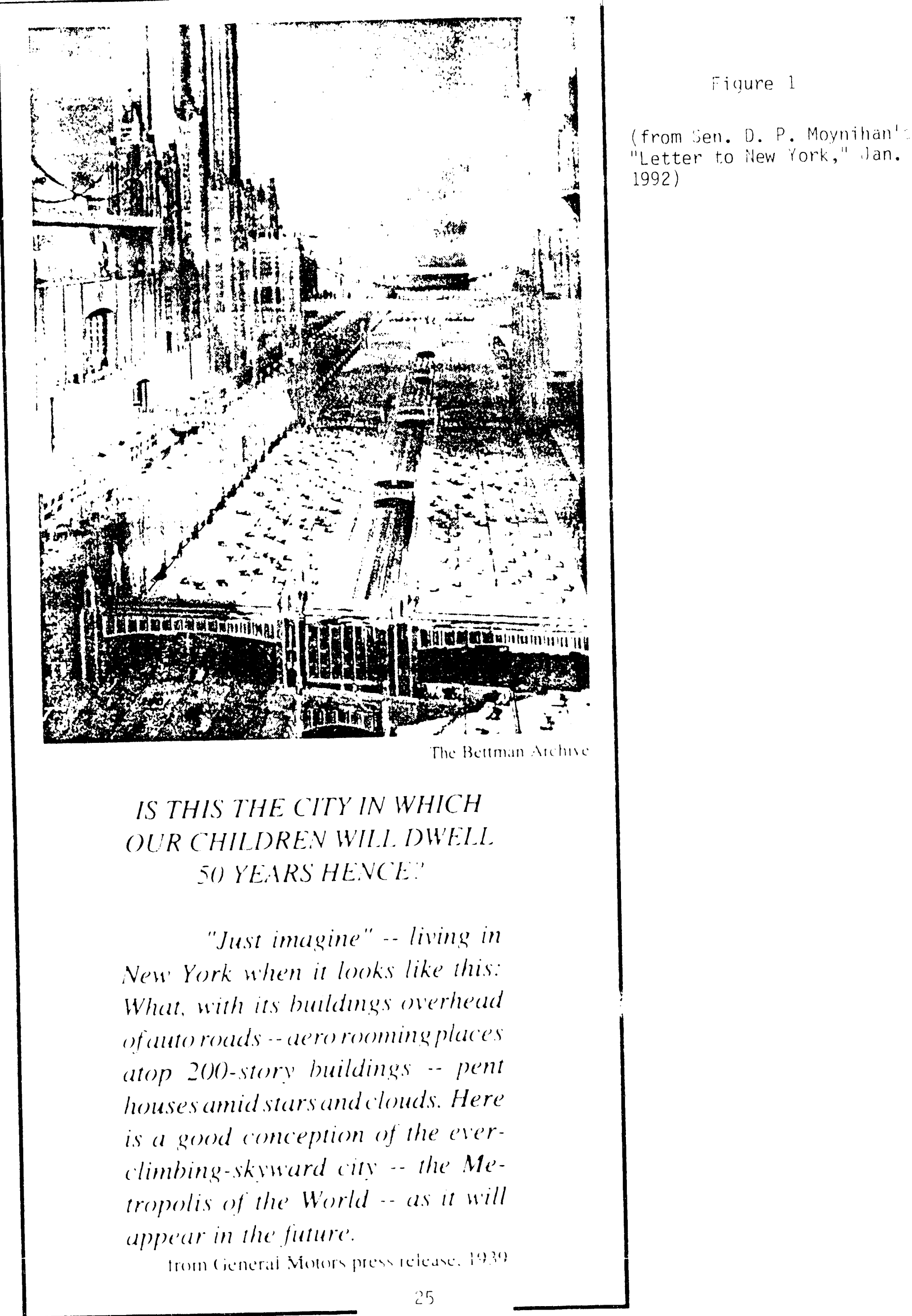


Figure 2

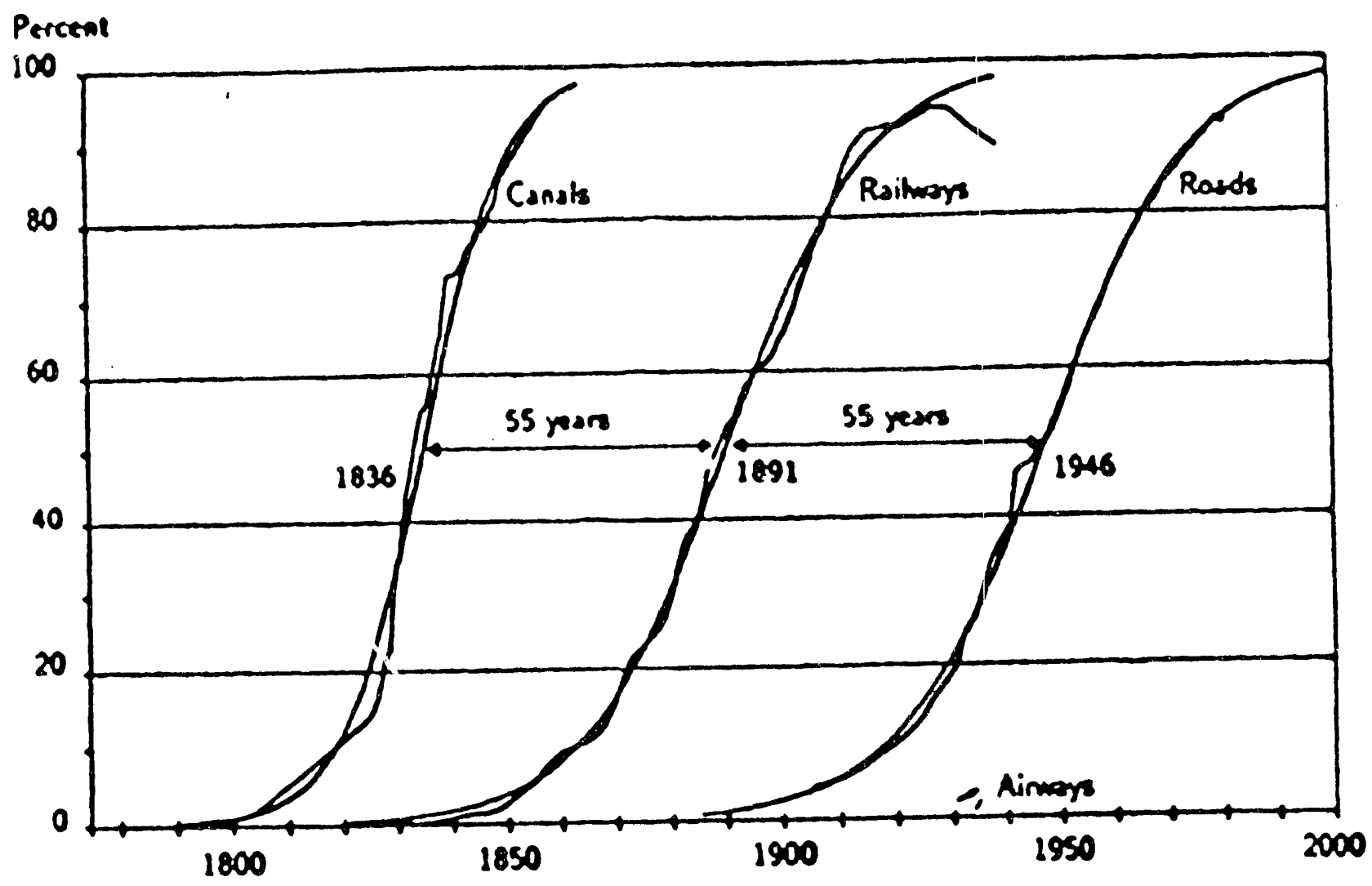

Growth to limits of canals, railroads, and raads in the USA. (Grübler and Nalsi Eenovic, "Lvolution of Transport Systems: Past anci Future," IIASA, Laxenburg, Austria (1991)) 


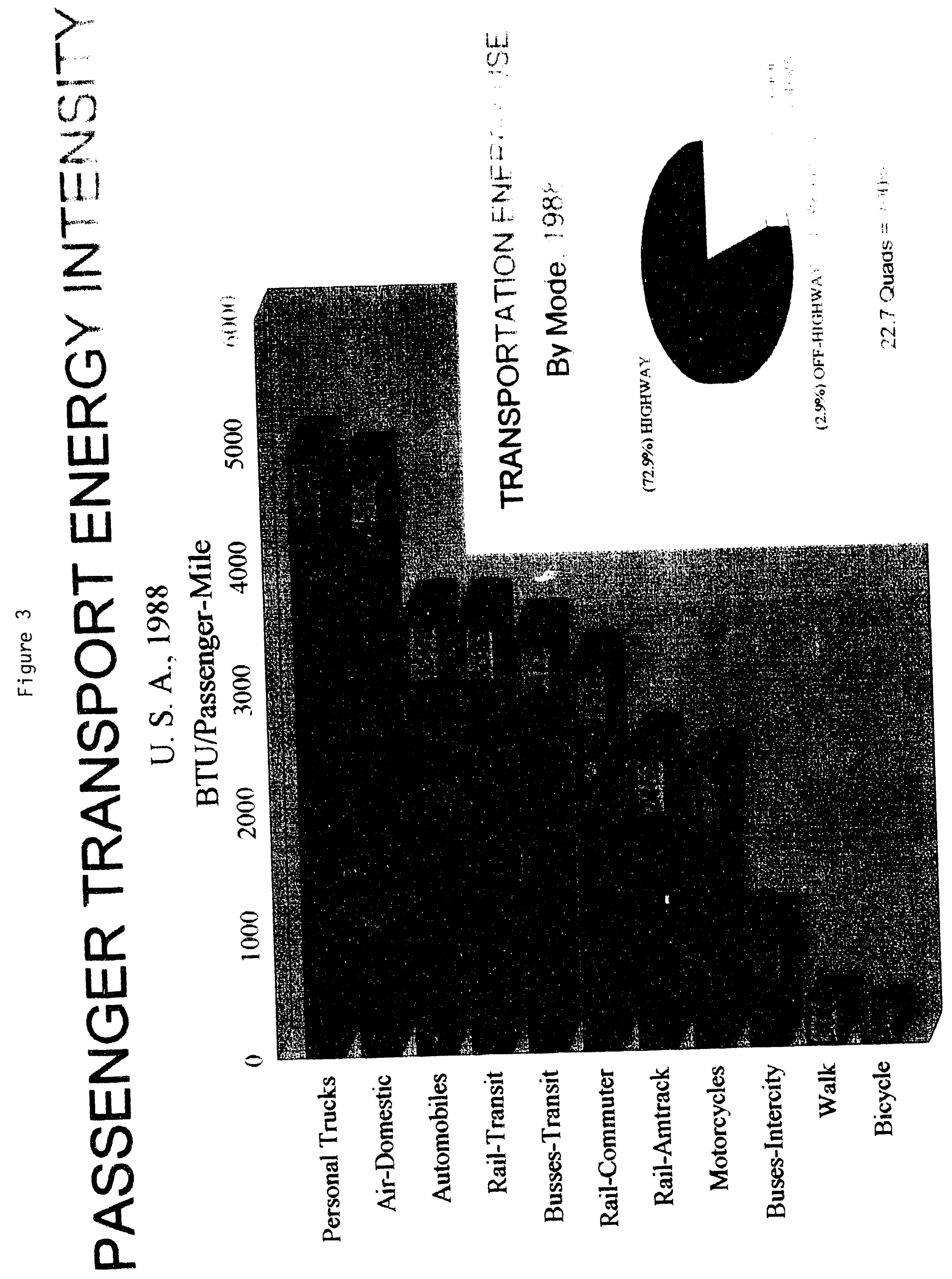




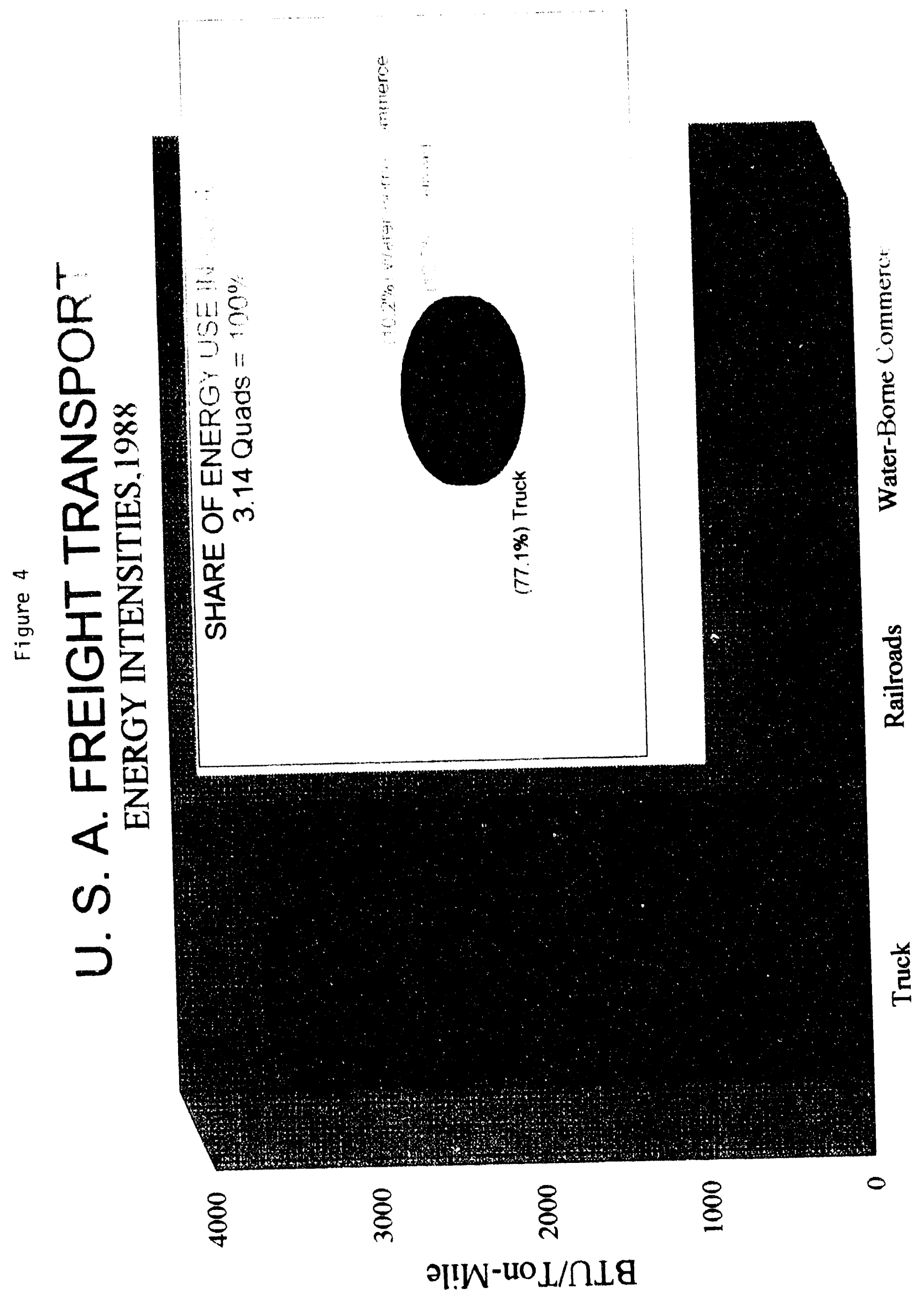




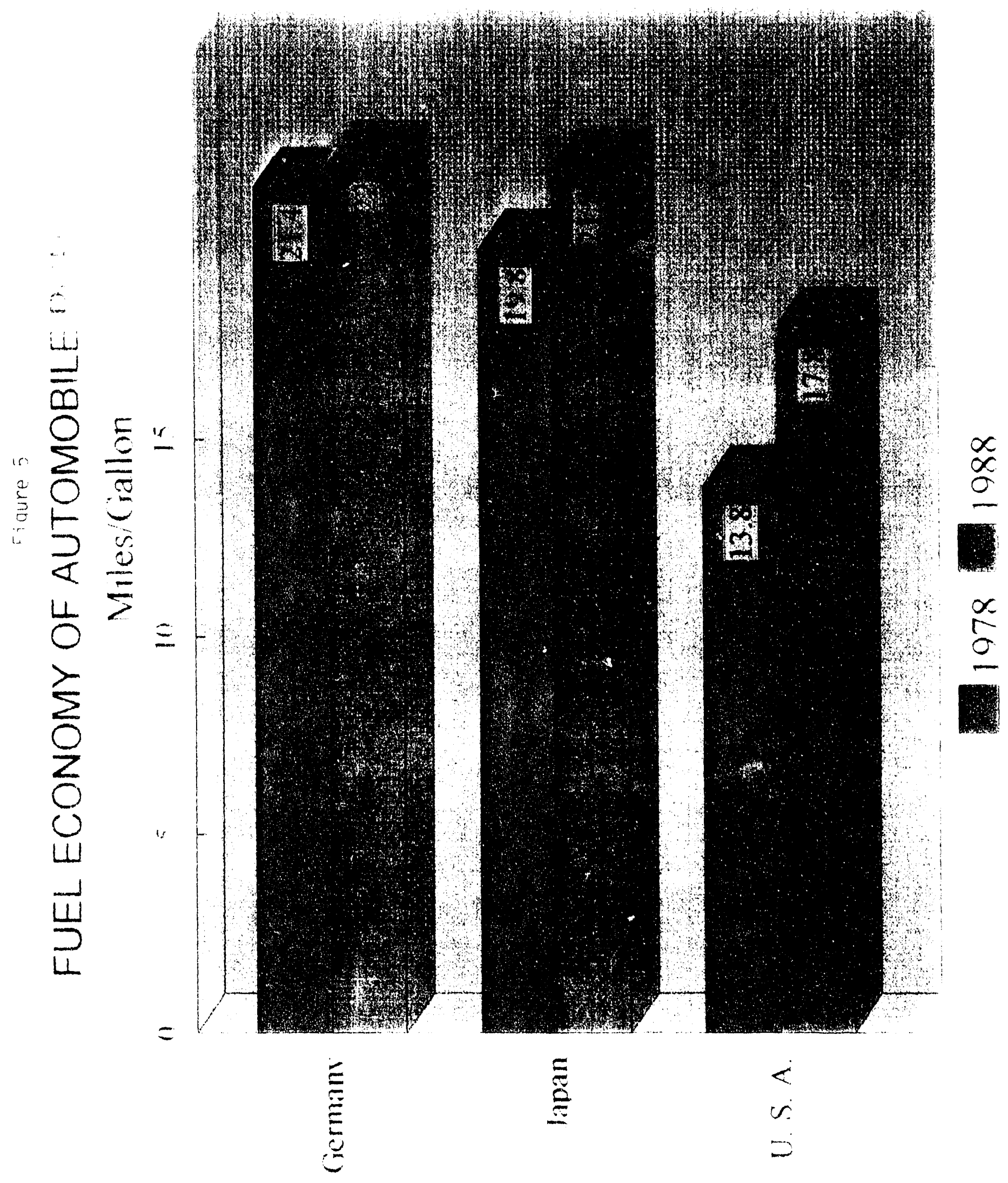


Figure 6

ENERGY USE AND THE U.S. ECONOMY.

INDEX OF U.S., GDP, AND ENERGY INTENSITY

(Office of Technology Assessment, BP-E-57 (1990))

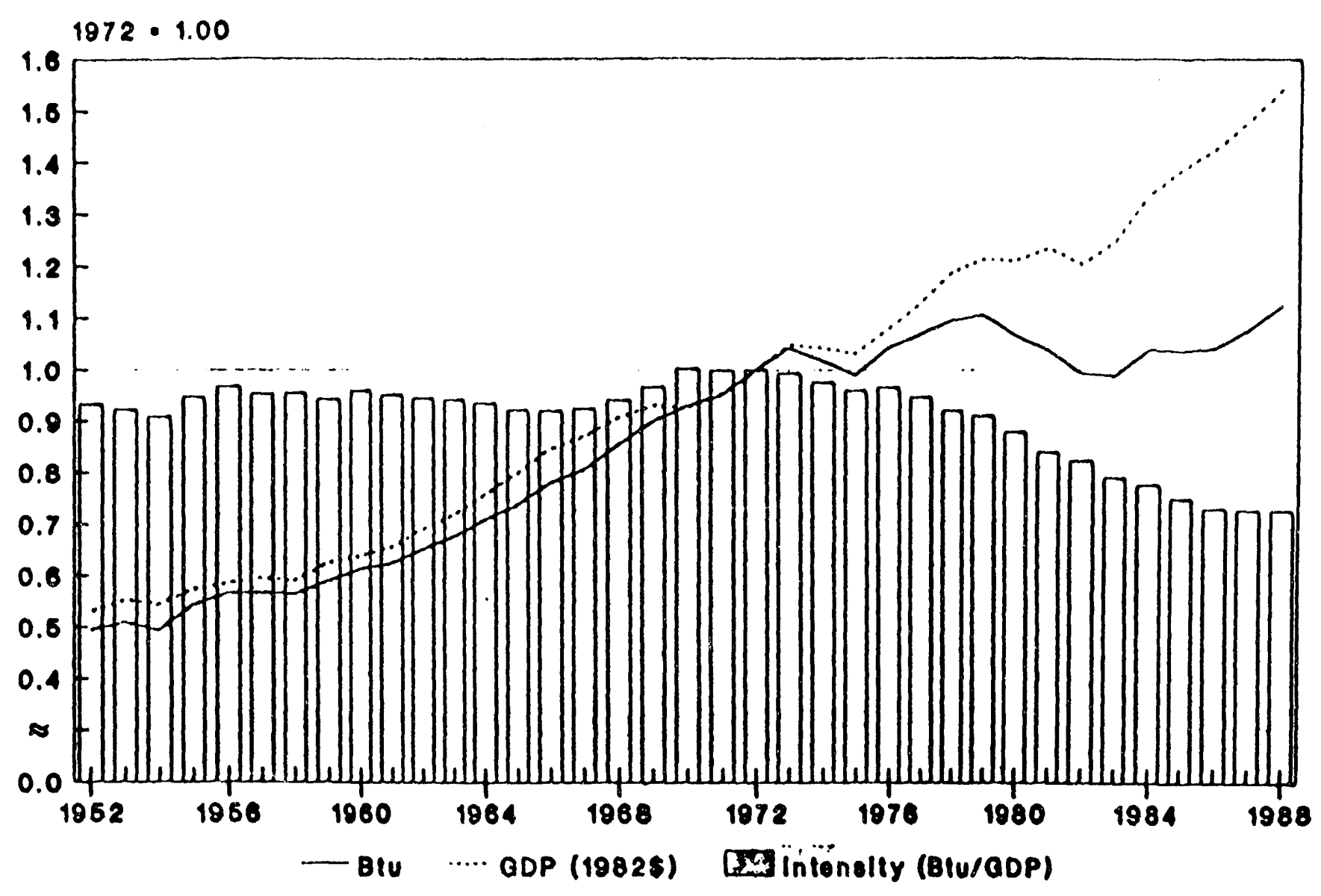




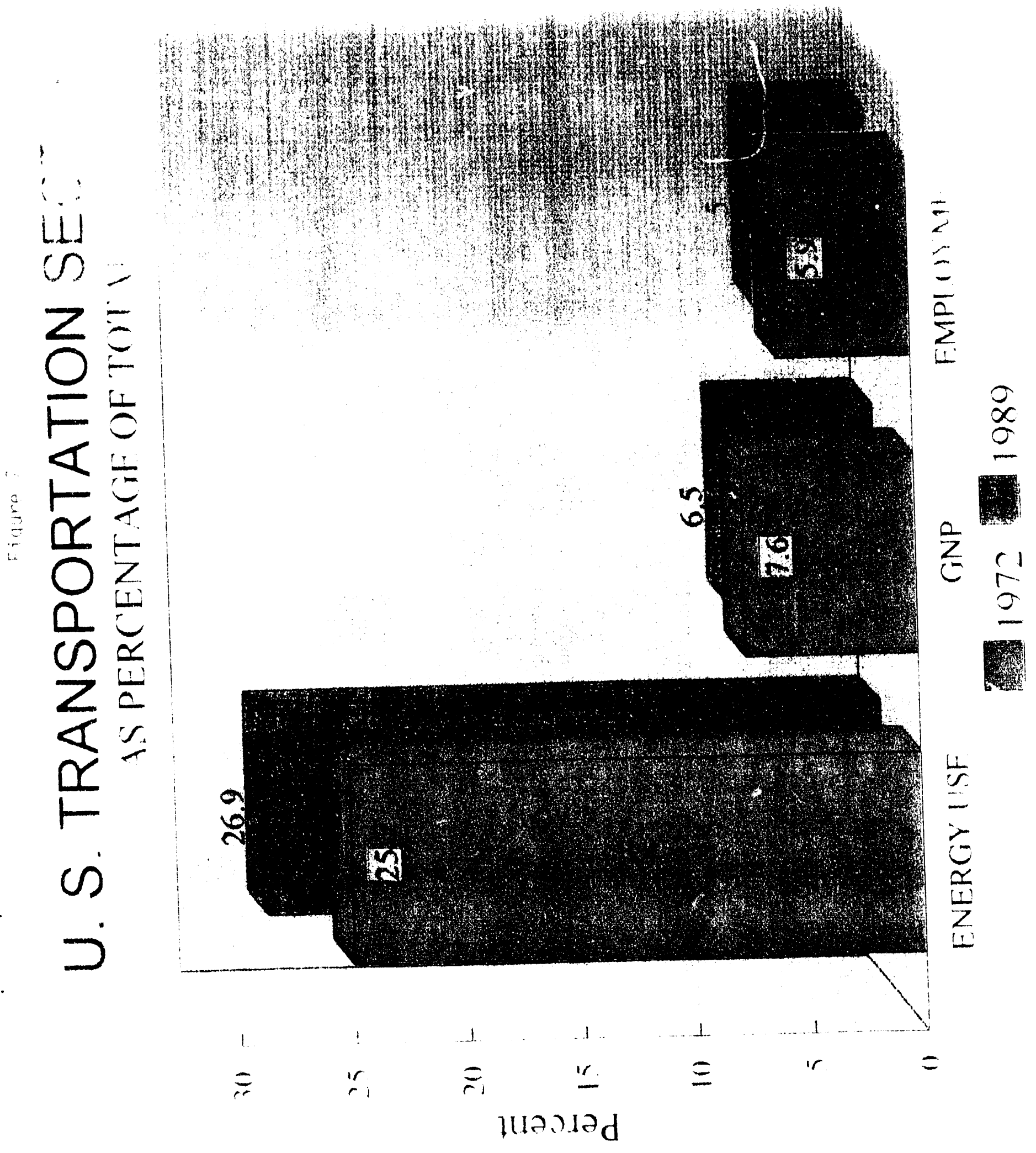




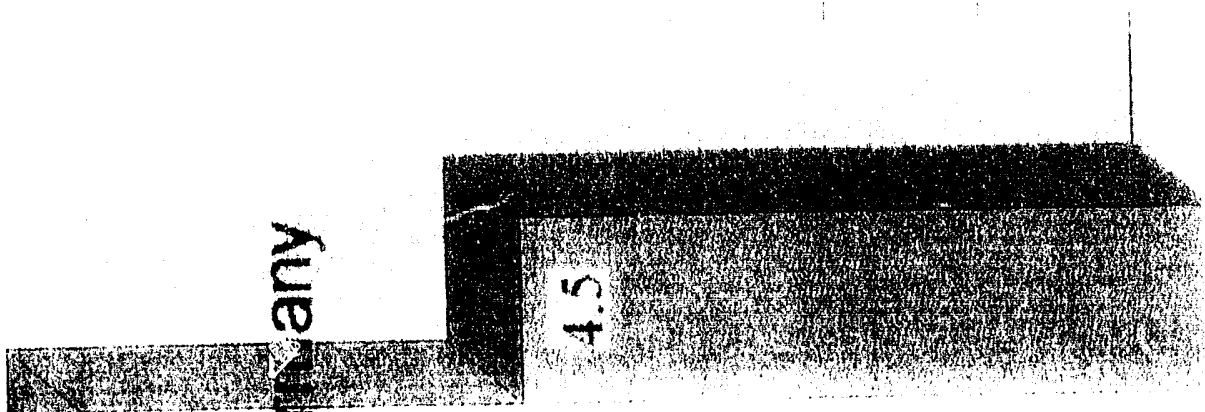

.

a

$$
0
$$

앙장

U1
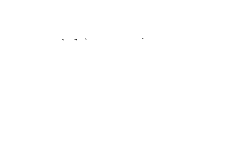

$=$

$z$
0
$\frac{1}{\sigma}$
$\frac{1}{\alpha}$
0
0
$\frac{0}{2}$
$\frac{1}{\alpha}$
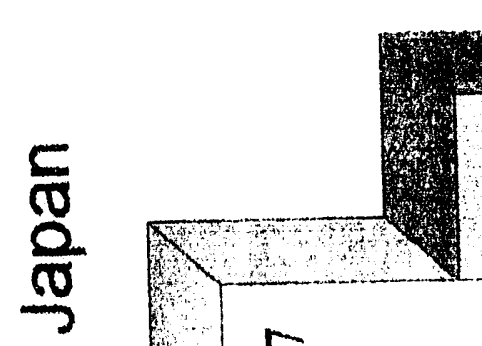

m

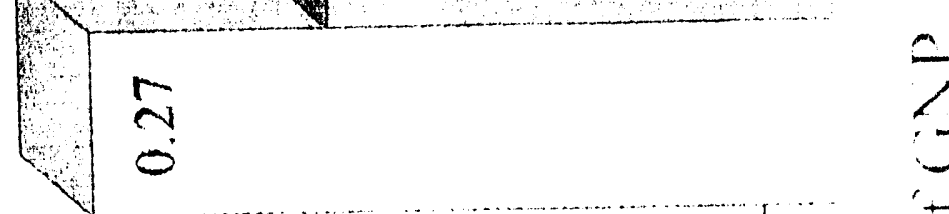

5
$\vdots$
$\vdots$
$\vdots$
$\vdots$
$\Xi$
$\Xi$

$$
\begin{aligned}
& \rightarrow \\
& \begin{array}{llll}
1 & 1 & 1 & \ddots
\end{array} \\
& \because=
\end{aligned}
$$

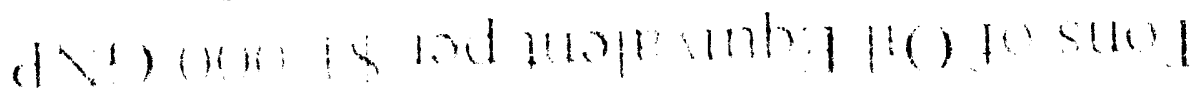



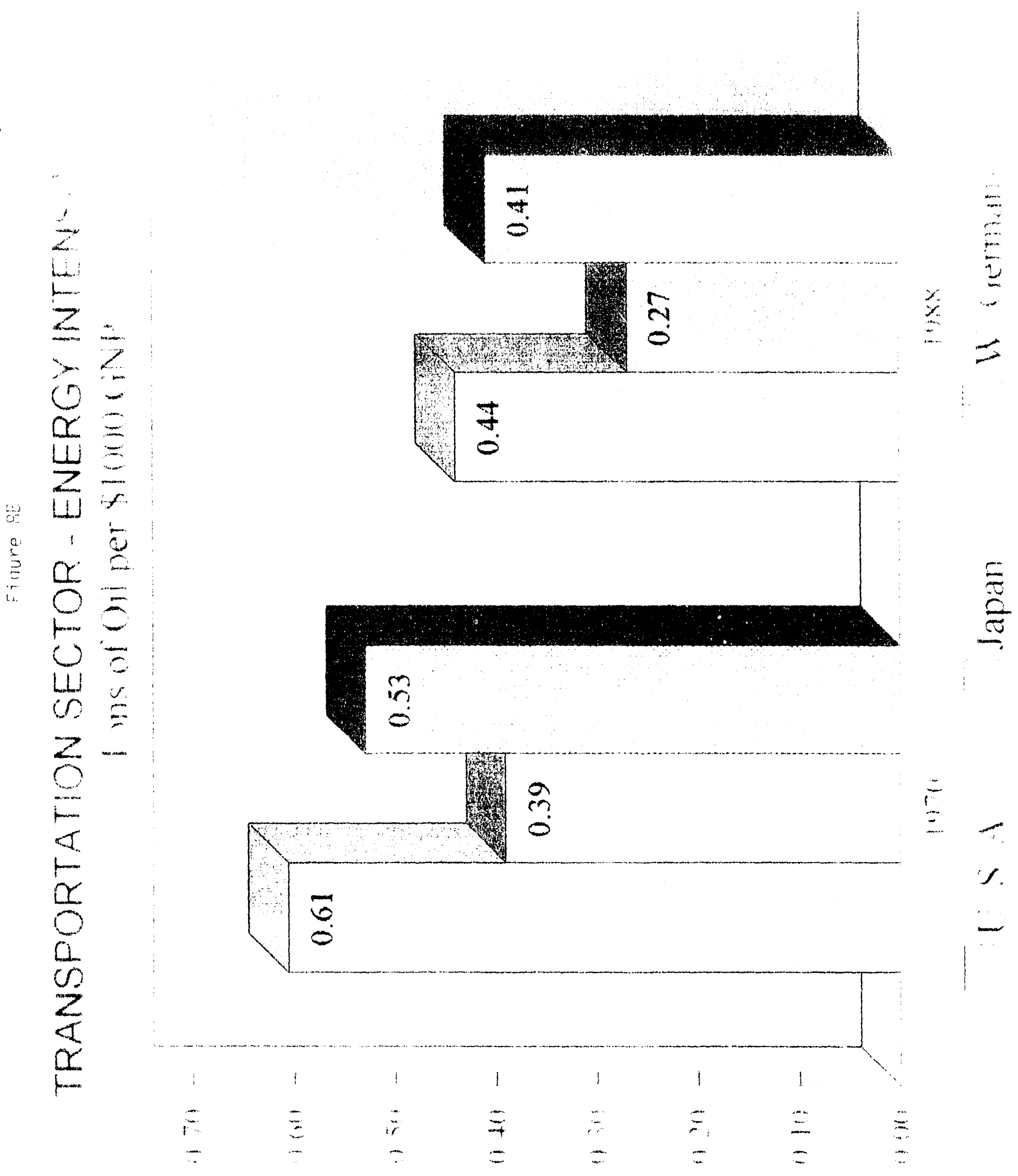


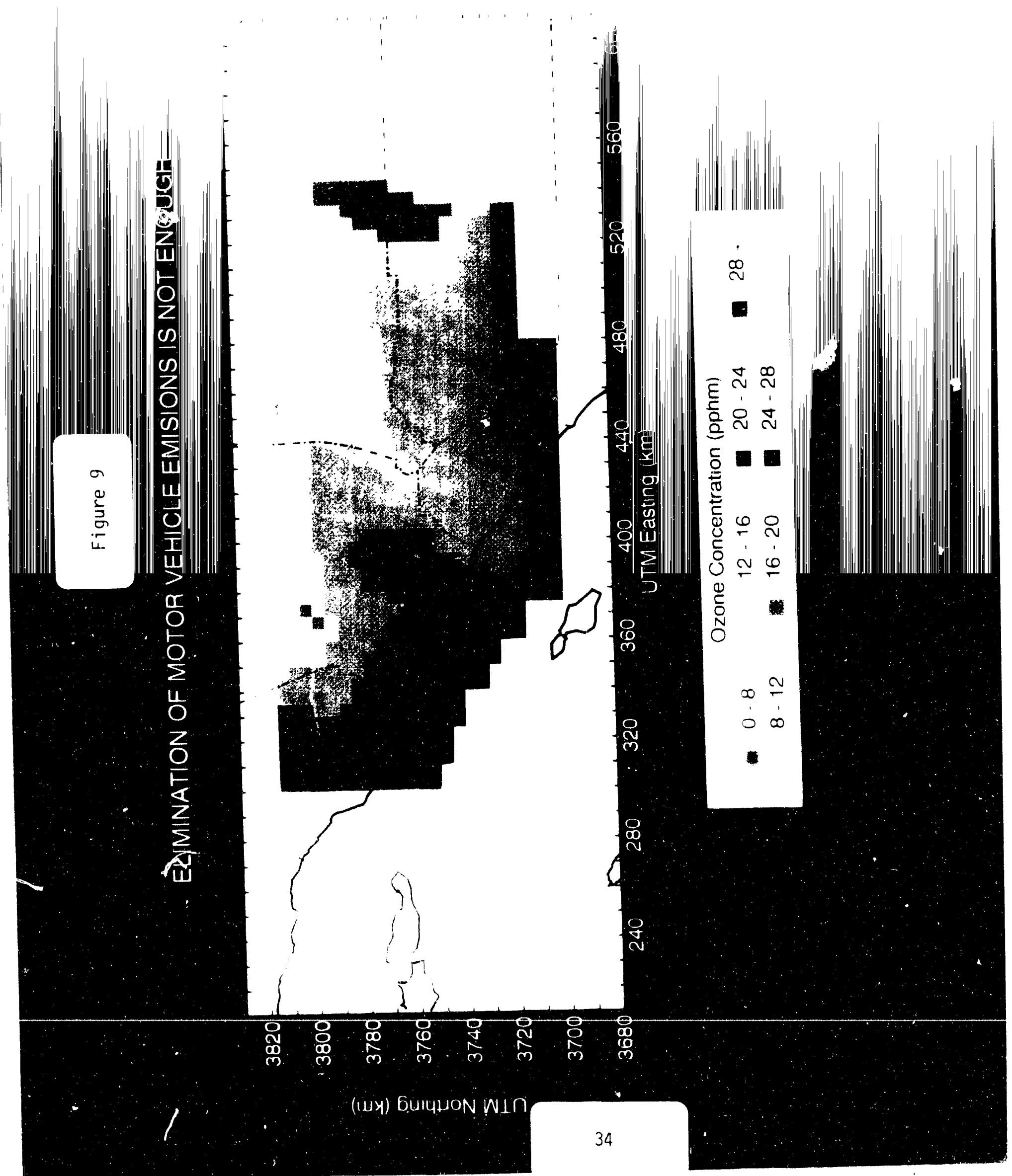




\section{TifersonalkTanisportatiom shergy Consumption Figure 10}

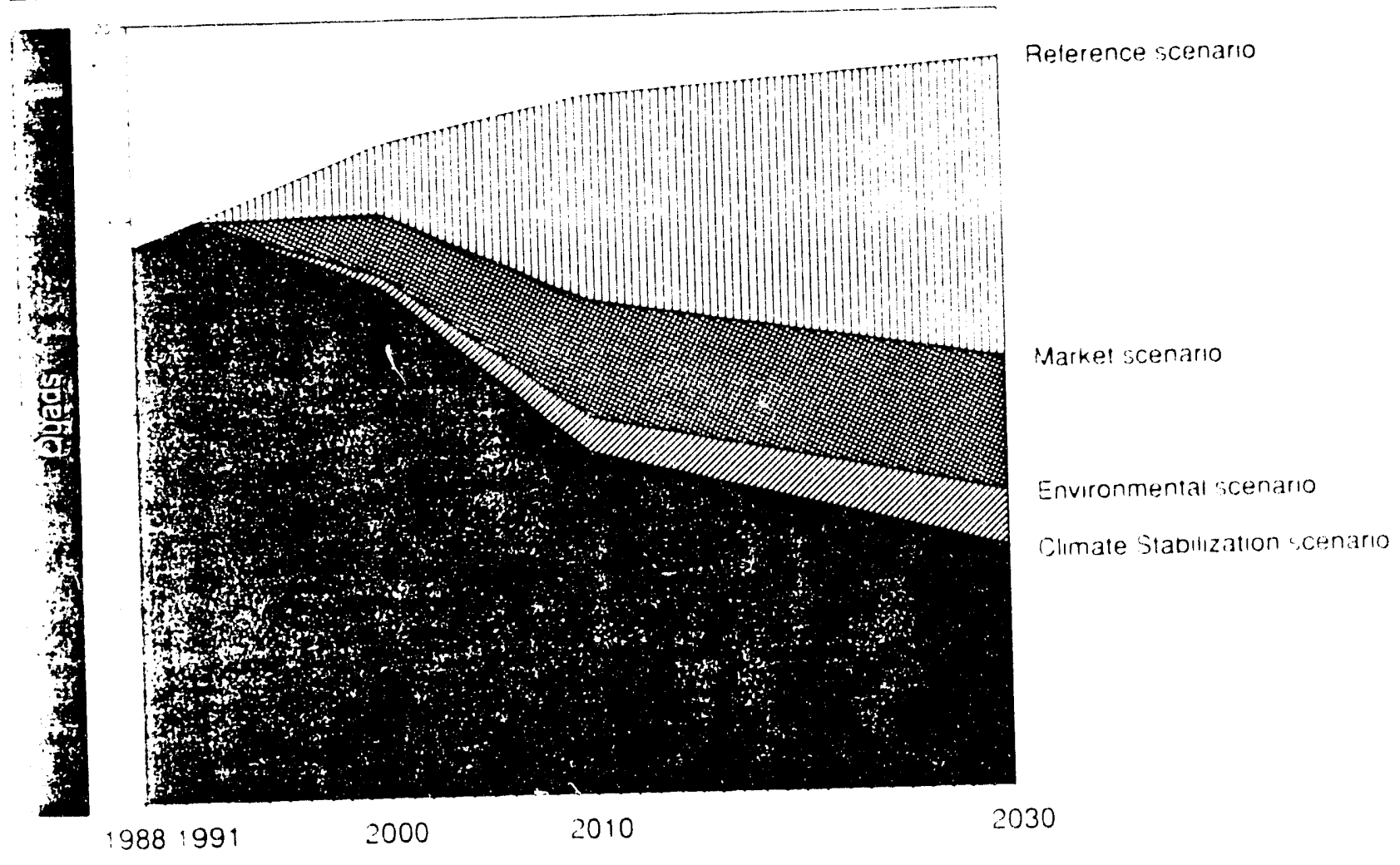

\section{Aleightianransportatiom Ehengy Consumptiom Figure iOA}
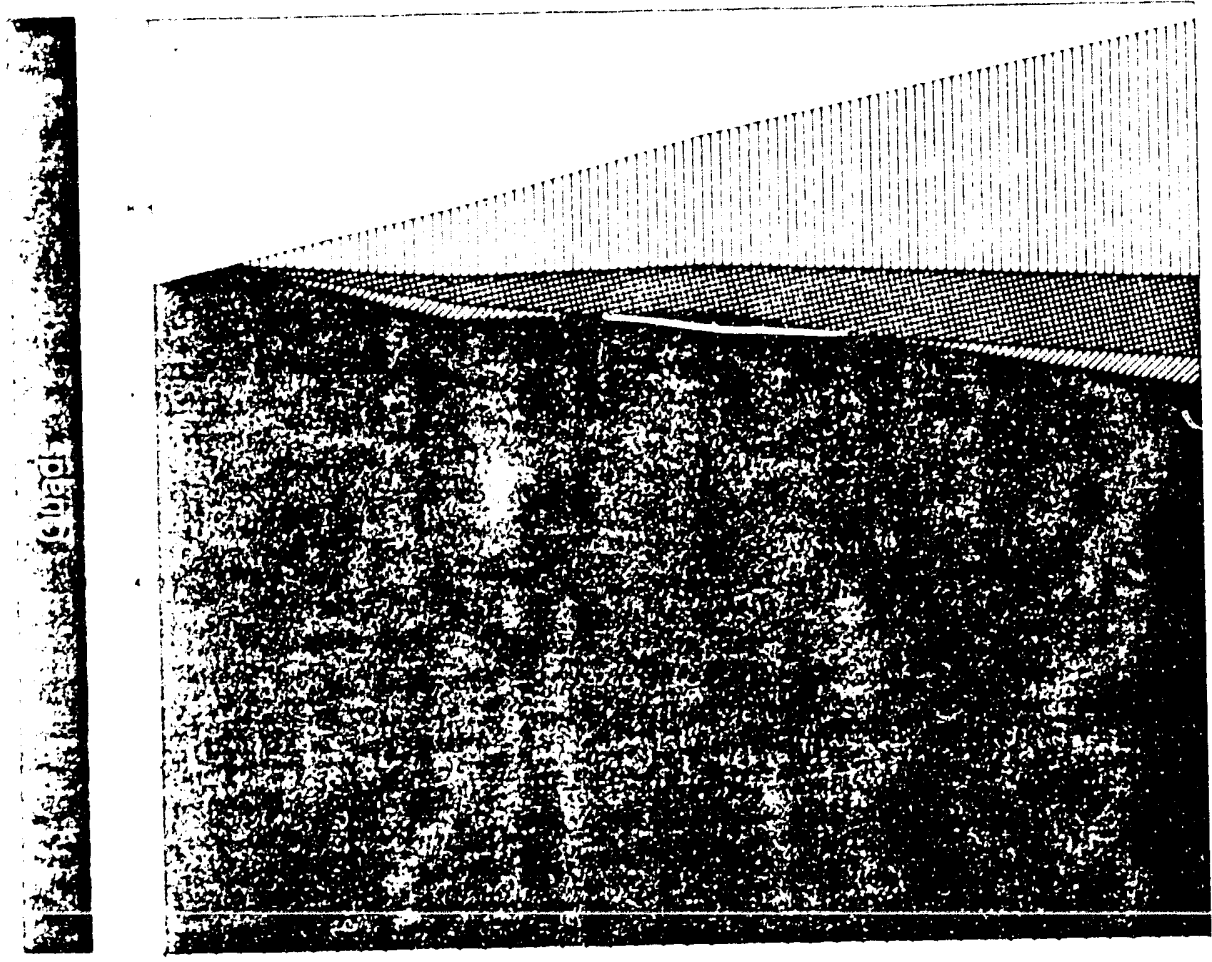

Relerence icenario

Markel sceniaro

Environmental scenario

Climate stadilization coenario

Source: "AMERICA" OMESG

CHOLCE's - Envesting in t tromes

Economy and a Gean Enviroment,

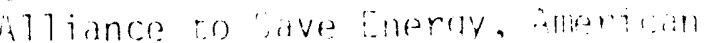

councis for heray-fficient an-

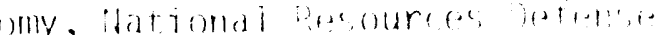

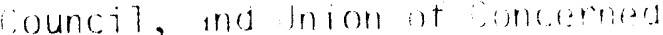

cientiote me nilon it encerne

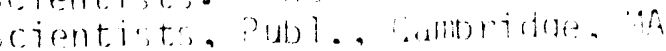

(199)!

$: 988: 991$

2000

2010 
Appendix I

Supplemental Data

A. Energy Profile

B. Energy/Economy Data

C. Emission 
Appendix I

A. Energy Profile

I.A. 


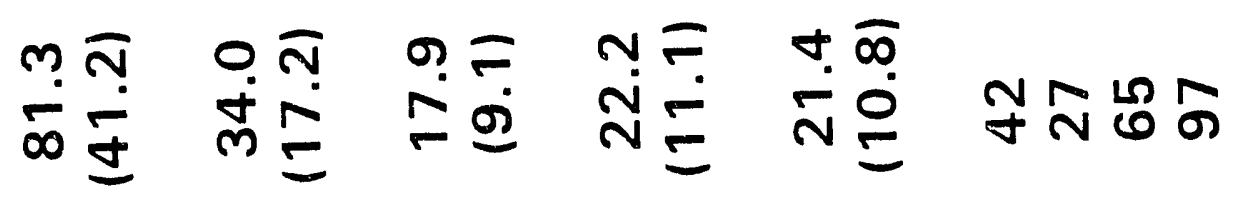
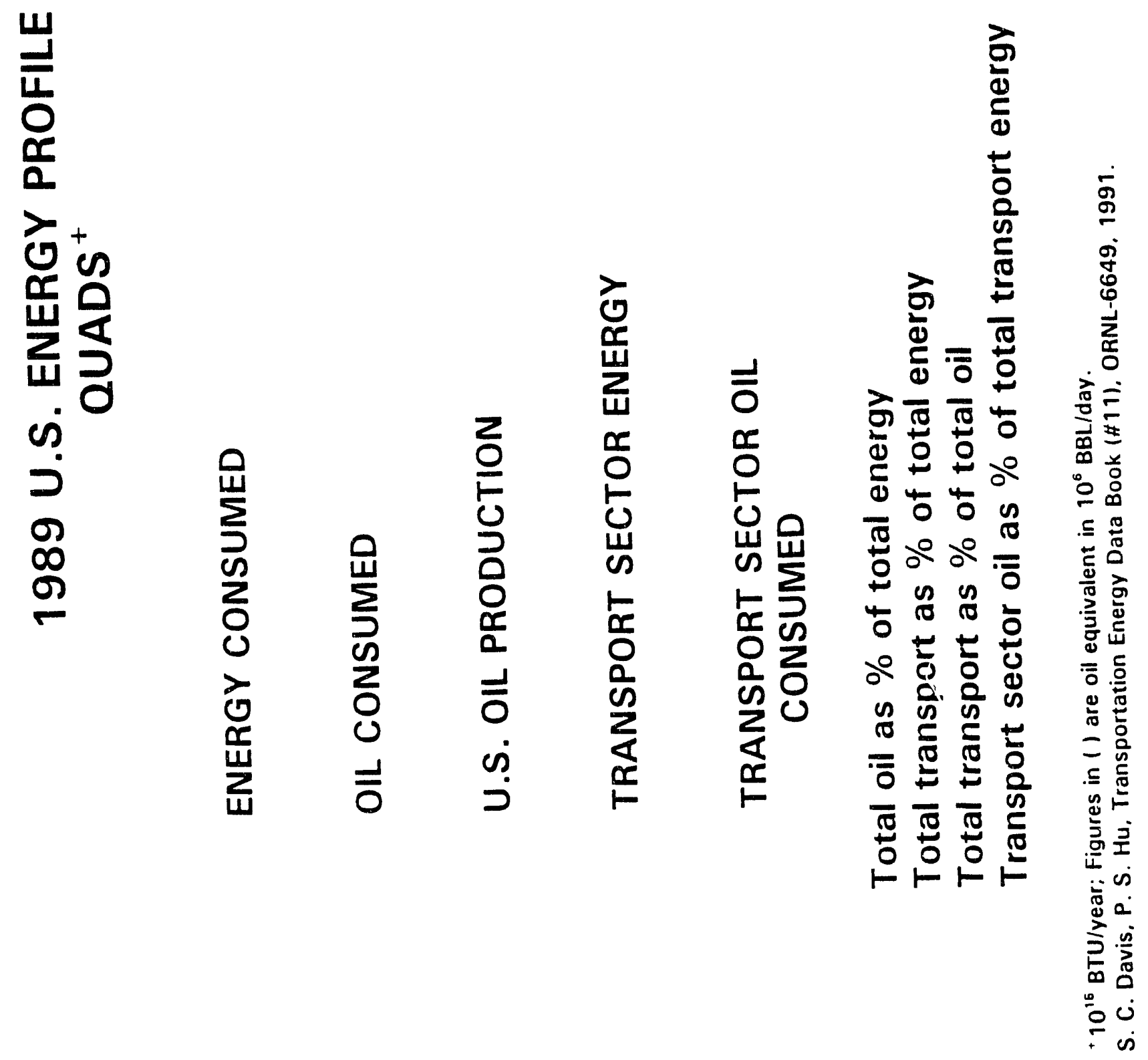


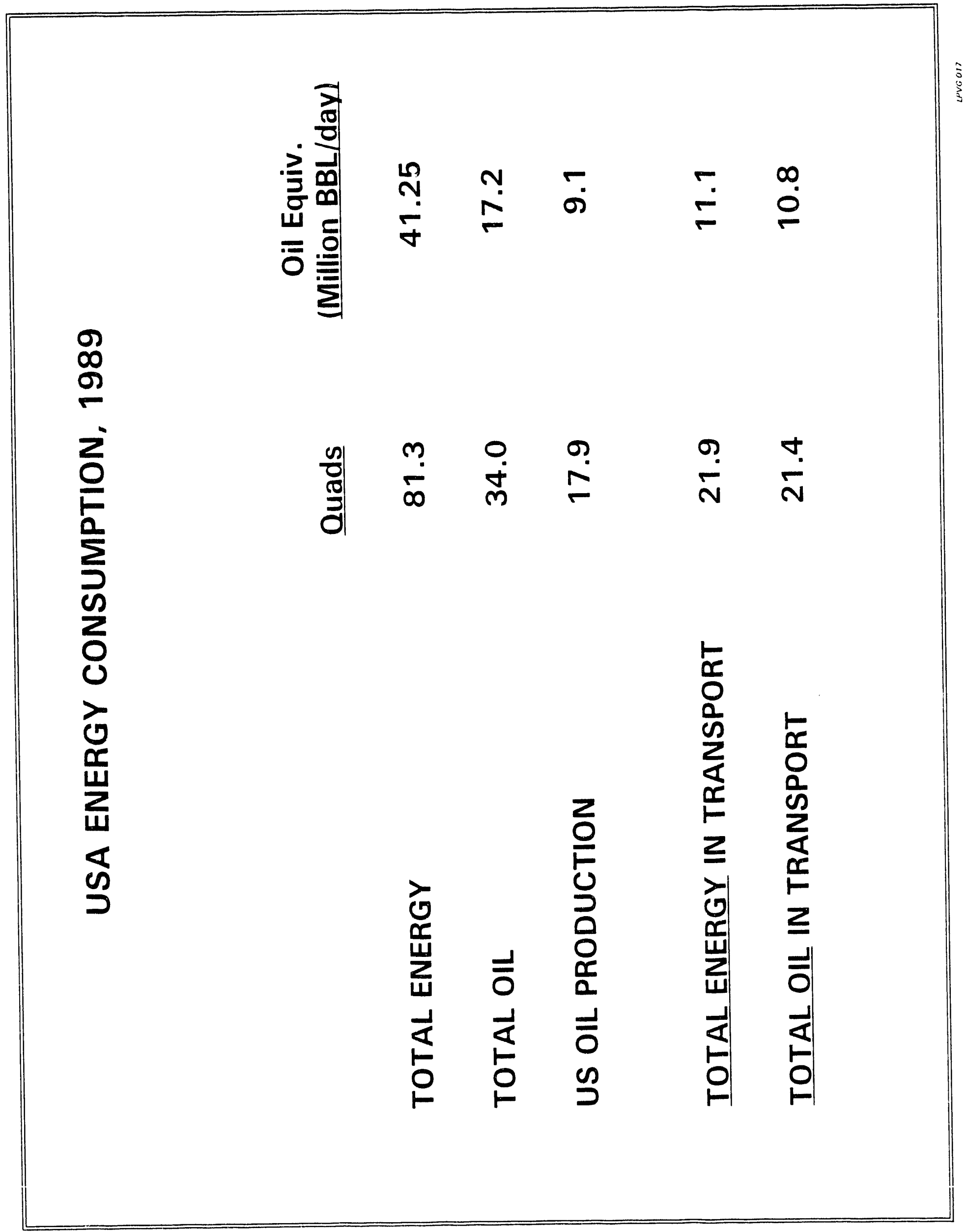




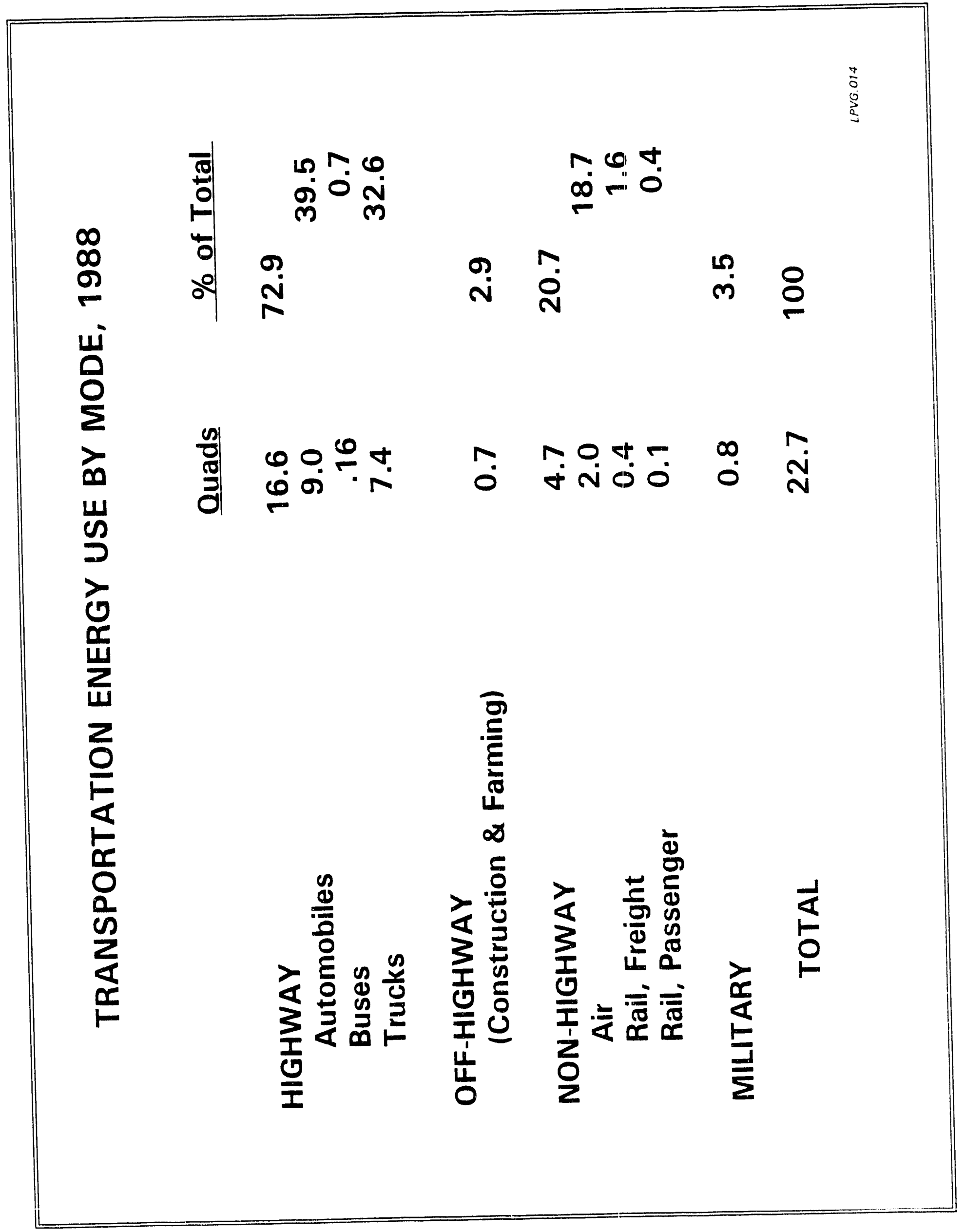




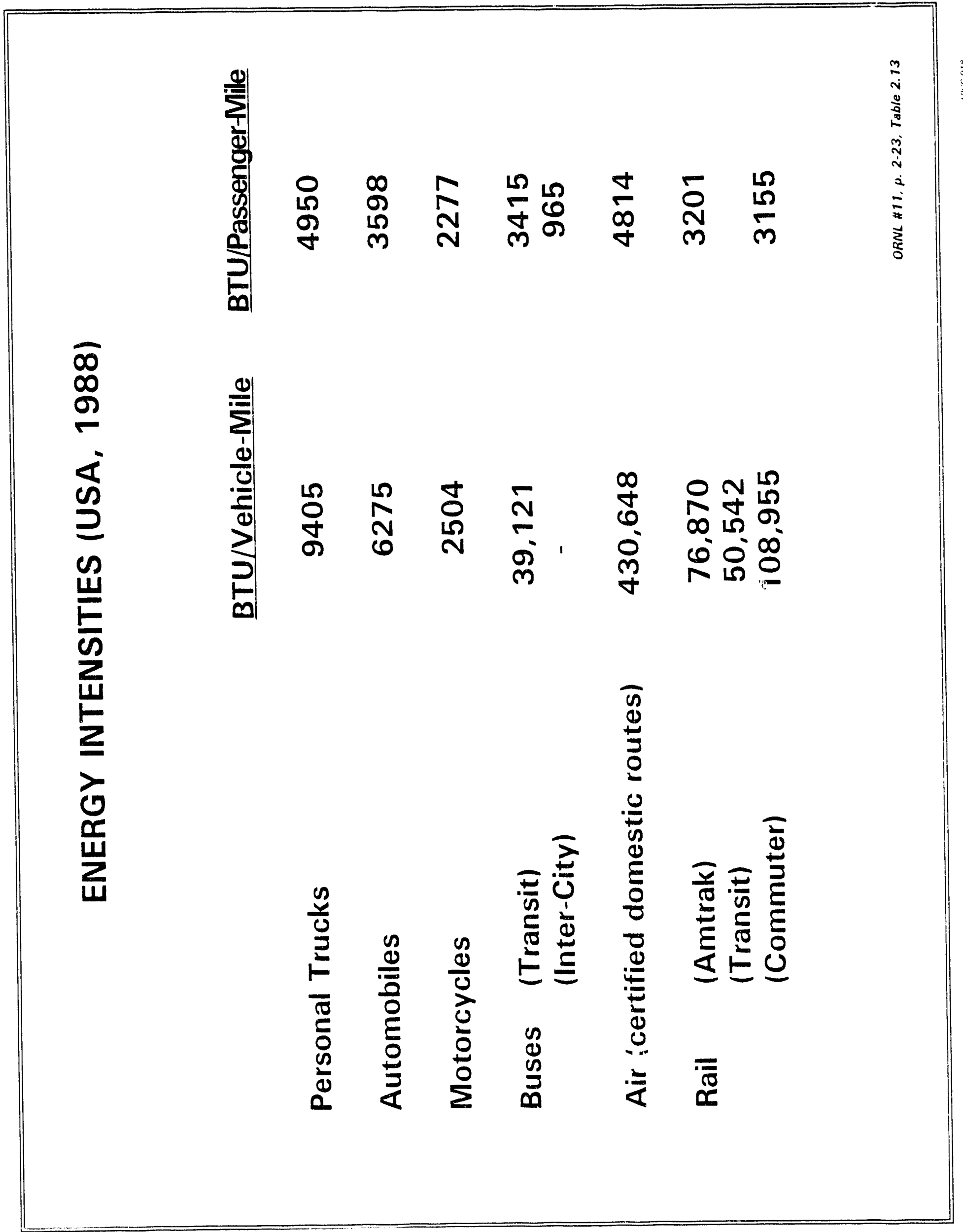

I. A. -4 


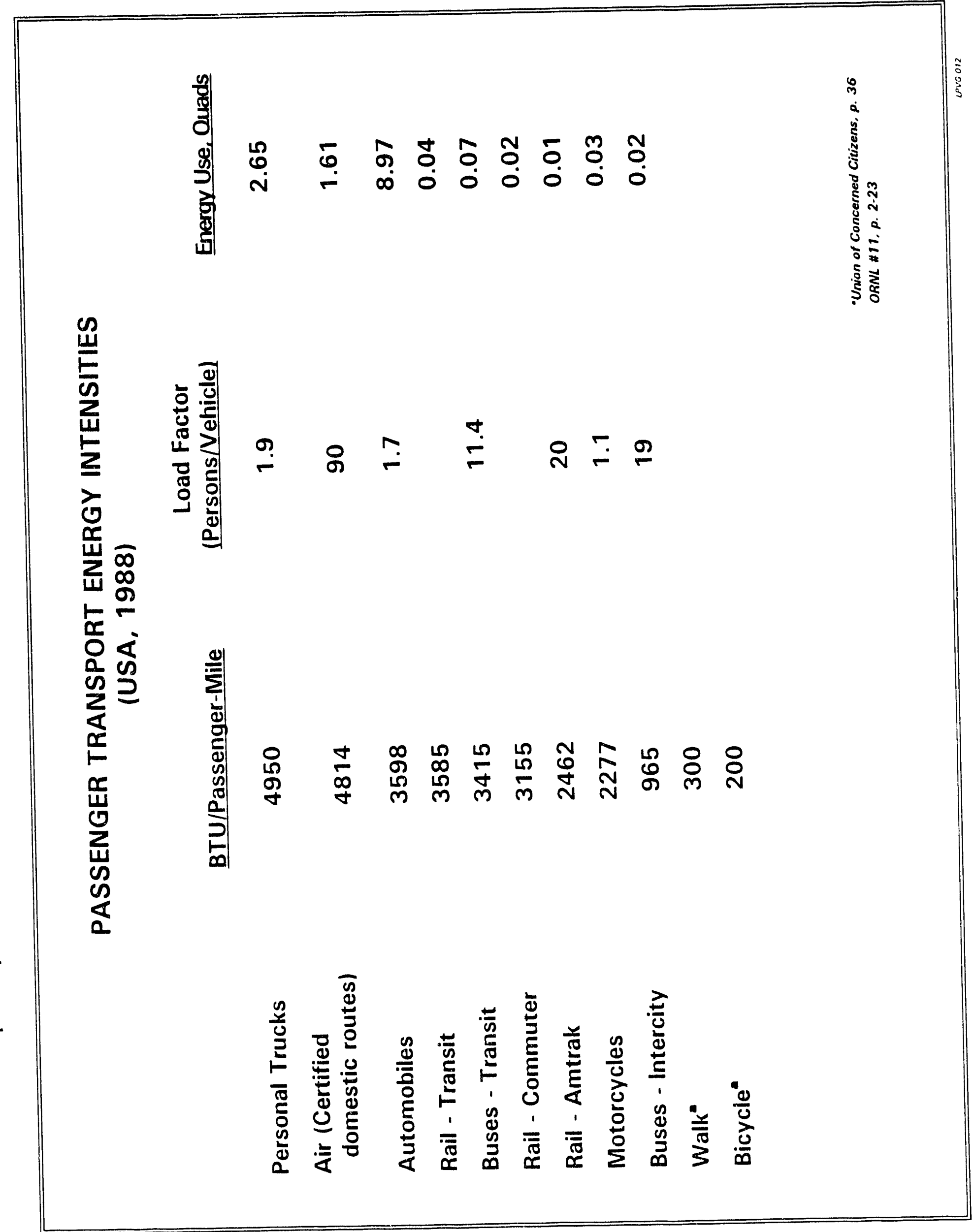

$$
\text { I. A. }-5
$$


Marc Ross: Ann. Rev. Energy 1989: 131-71

ENERGY AND TRANSPORTATION

Table 2 Transportation activity and energy use, 1985*

\begin{tabular}{|c|c|c|c|c|}
\hline Mixde & $\begin{array}{l}\text { Energy } \\
\text { (quads) }\end{array}$ & $\begin{array}{l}\text { Activity } \\
\text { unit }\end{array}$ & $\begin{array}{l}\text { Actuvity } \\
\text { (trillions) }\end{array}$ & $\begin{array}{l}\text { Energy-intensity } \\
\text { (thousand Btu per unit) }\end{array}$ \\
\hline \multicolumn{5}{|l|}{ Passenger } \\
\hline automobiles' & 9.16 & VM & 1.29 & 7.1 \\
\hline light Irucks s & 2.60 & $V M$ & 0.28 & 9.3 \\
\hline buses & 0.15 & PM & $0.11^{e}$ & $1.4^{e}$ \\
\hline rail & $0.05^{\prime}$ & PM & 0.015 & $3.5^{1}$ \\
\hline alr & $1.61^{2}$ & PM & 0.3 .36 & $5.0^{k}$ \\
\hline subtotal & 13.57 & & & \\
\hline \multicolumn{5}{|l|}{ Freight } \\
\hline light trucks ${ }^{d}$ & 1.05 & $V M$ & 0.10 & 10.4 \\
\hline heavy Inucks & 2.40 & $\mathrm{TM}$ & 0.7 & 3.4 \\
\hline rat $\left.\right|^{n}$ & 0.45 & TM & 0.91 & 0.49 \\
\hline marine '-domestic & 0.30 & TM & 0.89 & 0.34 \\
\hline -foreign & 0.75 & Ibs & 1.54 & 0.5 \\
\hline pipelines' & $0.55^{\prime}$ & TM & 0.26 & $2.1^{\prime}$ \\
\hline subtotal & 5.50 & & & \\
\hline \multicolumn{5}{|l|}{ Miscellaneous } \\
\hline military & 0.70 & & & \\
\hline fecreational txoats & 0.22 & & & \\
\hline general dvation & 0.14 & & & \\
\hline subtotal & 1.06 & & & \\
\hline Grand total & 20.12 & & & \\
\hline
\end{tabular}

- Adapred from Tabie 1.10 (Rels. 2.3) and Table 1.

APM. passenger-miles: VM, vehicle-miles; lbs, pound hipped: TM, lan-miles

- In-ludes inotorcycles

"Inder 10.000 lbs

Assumes (xcupancy of 20 passengers in schxol huses. The energy-Intensily of urtian transil huses is stated to be 36 thousand Btu/PM.

'Includes lowses in generatıng and distributing electricirs

"Freighiactisily, responsible perhaps for 10.05 quad. is included Energy use is purchases of Jomesic fuel by domestic and international cartiers. The energy-intensity in based on fotal luel used. roughly corrected for treight activities.

"Table 3.9 of Refs. 2 and 3

'Tubles 35 and 36 or Refs.? and 3

- Vatural gas pipelines only. Activity is based on total consumption of natural gas $(1)$ and assumed average transpomation of 620 iniles 


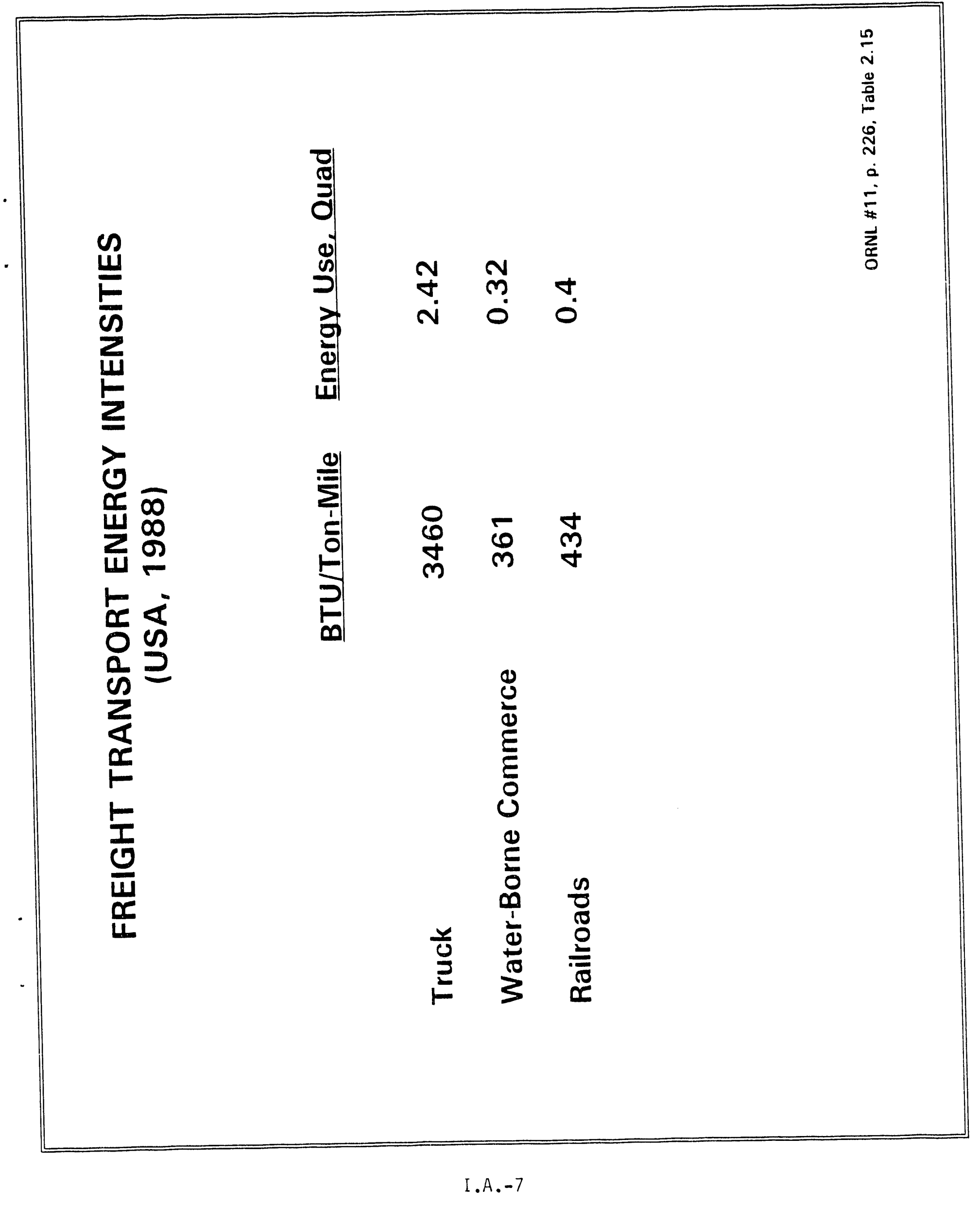




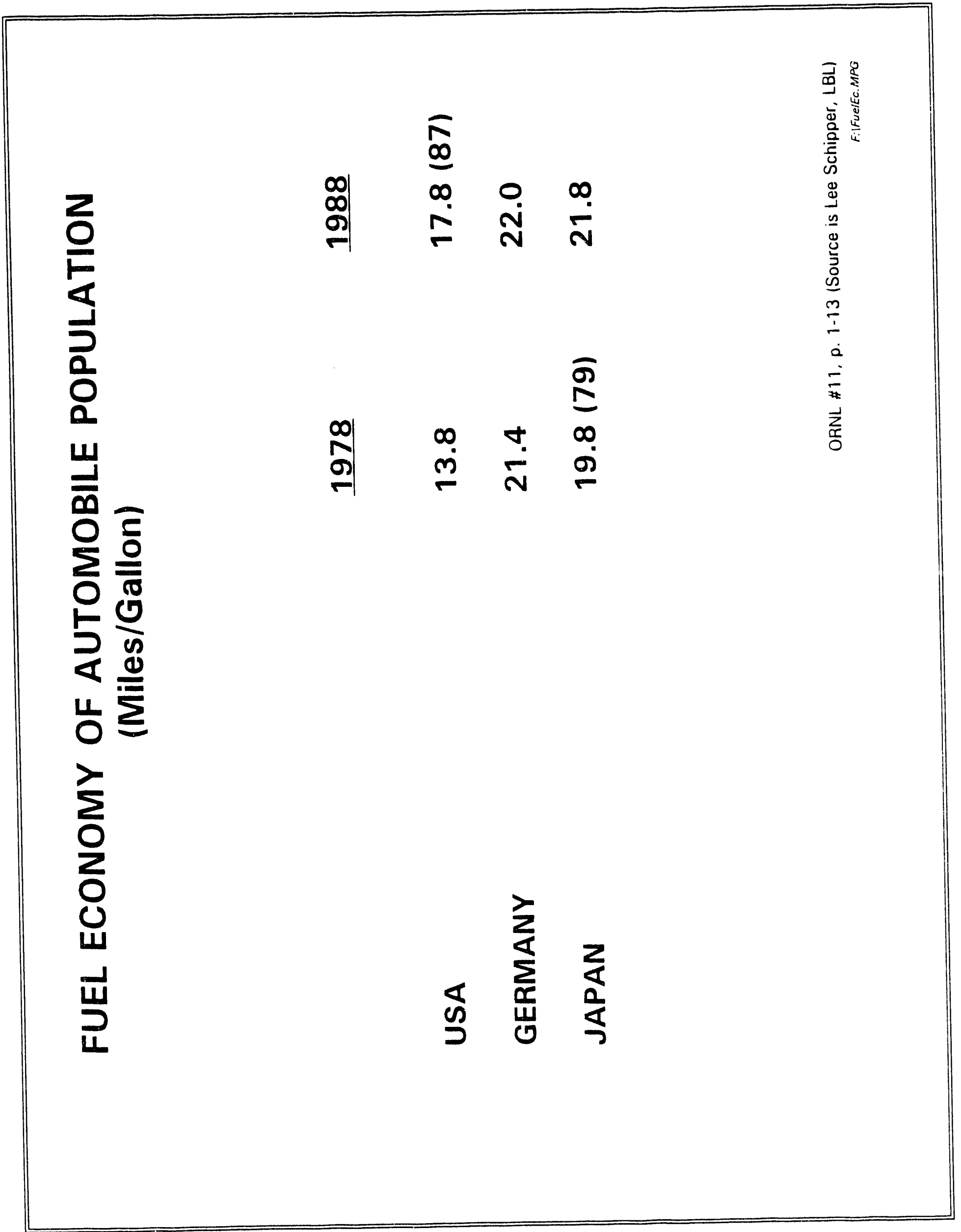

I . A. -8 
Appendix I

B. Energy/Economy Data

I.B. 


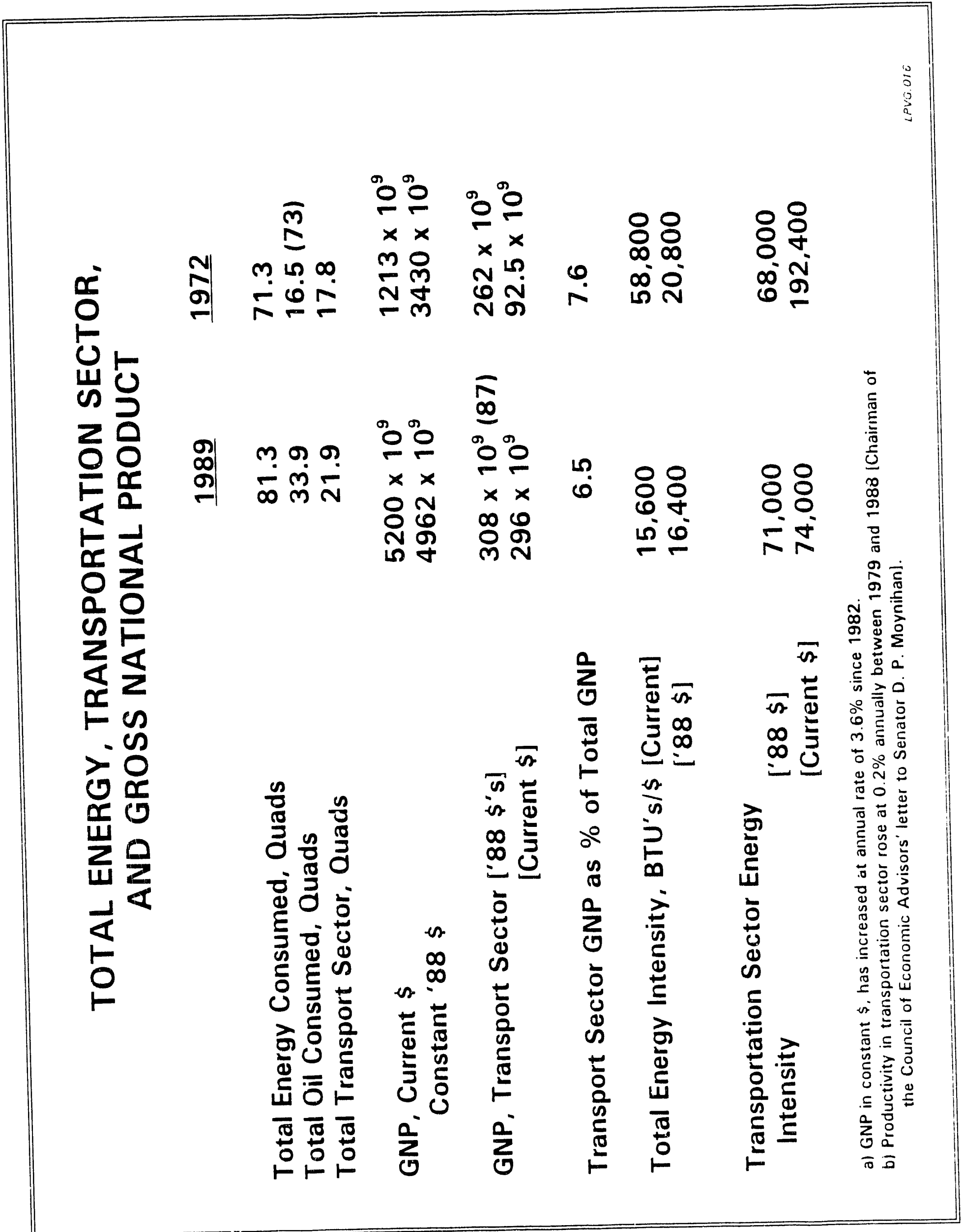




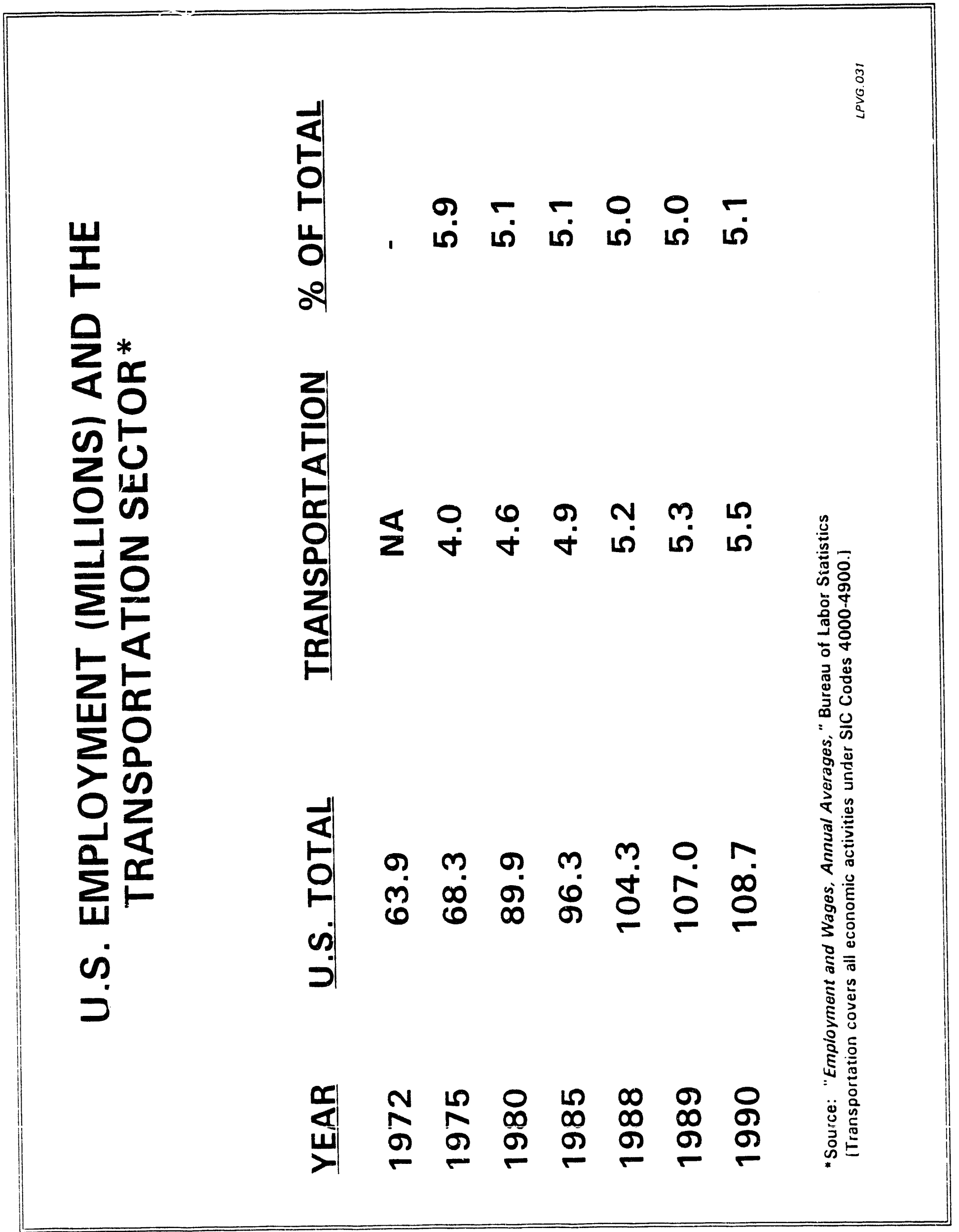

I.3. -2 


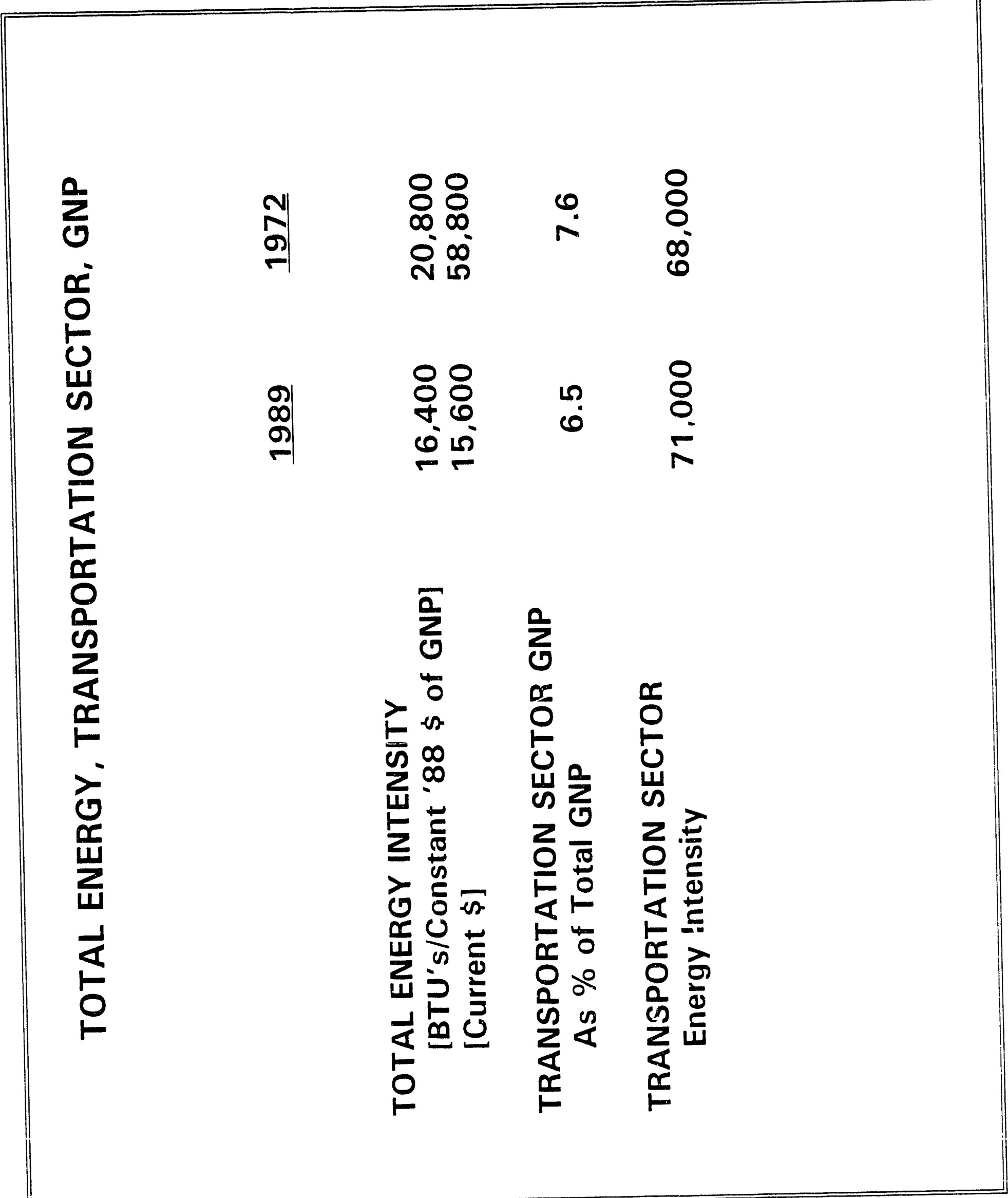

I. B. -3 


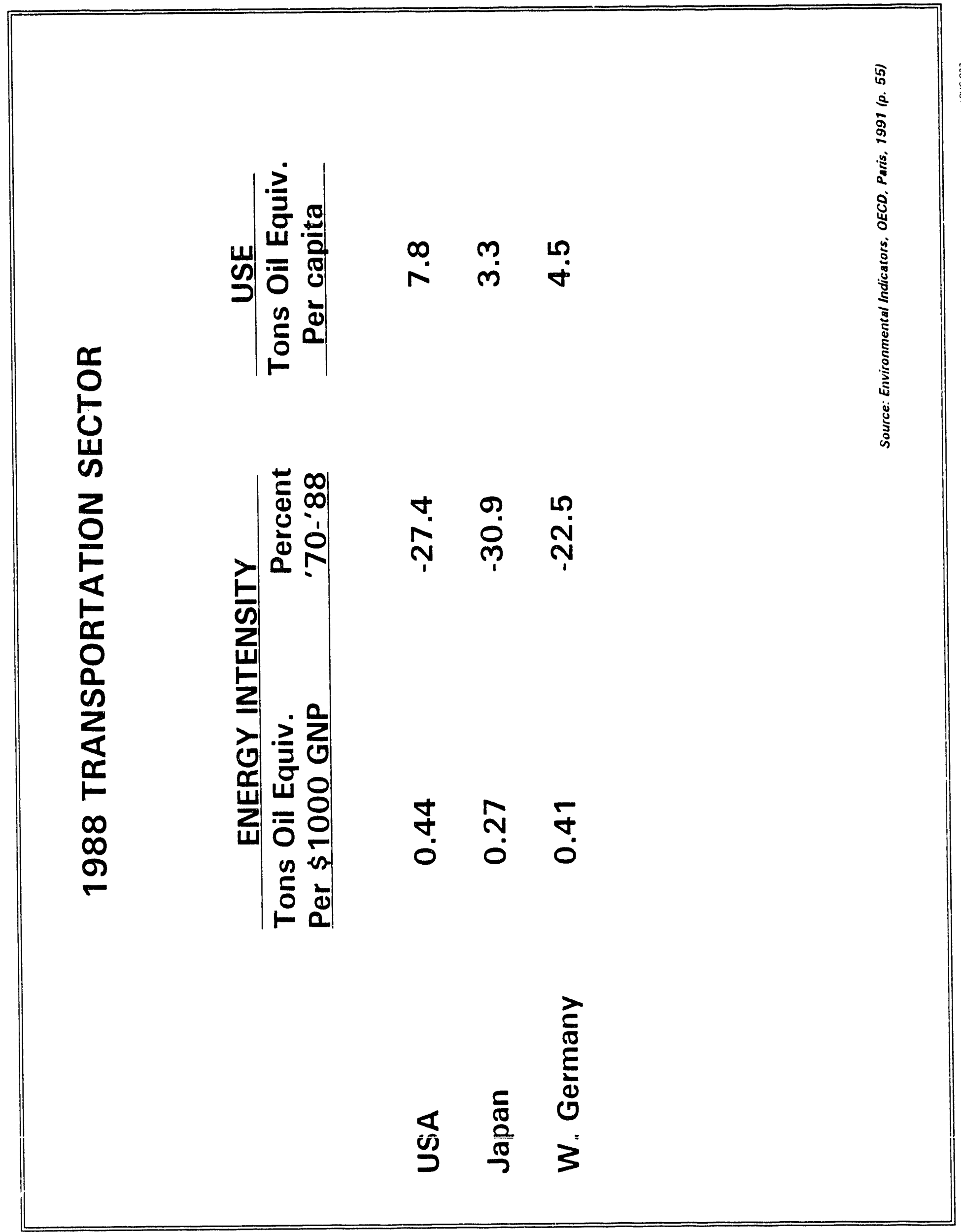

I. B. -4 
The total gross national product (GNP), in constant dollars, has increased at an average annual rate of $3.6 \%$ since 1982 In 1987, the GNP of the transportation industry accounted for $6.5 \%$ of the total GNP.

Table 2.20

Gross National Product (GNP) as Relatod to Transportation, $1970-89$

\begin{tabular}{|c|c|c|c|c|c|}
\hline \multirow[b]{2}{*}{ Year } & \multicolumn{2}{|c|}{$\begin{array}{c}\text { Gross National Product } \\
\text { (billion dollars) } \\
\end{array}$} & \multicolumn{2}{|c|}{$\begin{array}{c}\text { Transportation } \\
\text { Gross National Product* } \\
\text { (billion dollars) } \\
\end{array}$} & \multirow{2}{*}{$\begin{array}{l}\text { Transportation } \\
\text { GNP } \\
\text { as a percent of } \\
\text { total GNP }\end{array}$} \\
\hline & Current & $\begin{array}{c}\text { Constant } \\
1988^{b}\end{array}$ & Current & $\begin{array}{c}\text { Constant } \\
1988^{\circ}\end{array}$ & \\
\hline 1970 & $1,015.5$ & $3,093.2$ & 76.3 & 232.4 & $7.5 \%$ \\
\hline 1971 & $1,102.7$ & $3,221.0$ & 85.6 & 250.0 & $7.8 \%$ \\
\hline 1972 & $1,212.8$ & 3.429 .8 & 92.5 & 261.6 & $7.6 \%$ \\
\hline 1973 & $1,359.3$ & $3,618.5$ & 102.0 & 271.5 & $7.5 \%$ \\
\hline 1974 & $1,472.8$ & $3,533.2$ & 103.8 & 249.0 & $7.0 \%$ \\
\hline 1975 & $1,598.4$ & $3,513.3$ & 107.1 & 235.4 & $6.7 \%$ \\
\hline 1976 & $1,782.8$ & $3,704.7$ & 127.5 & 264.9 & $7.2 \%$ \\
\hline 1977 & $1,990.5$ & $3,885.5$ & 146.6 & 286.2 & $7.4 \%$ \\
\hline 1978 & $2,249.7$ & $4,078.7$ & 165.9 & 300.8 & $7.4 \%$ \\
\hline 1979 & $2,508.2$ & $4,088.4$ & 178.8 & 291.4 & $7.1 \%$ \\
\hline 1980 & $2,732.0$ & $3,923.2$ & 181.8 & 261.1 & $6.7 \%$ \\
\hline 1981 & $3,052.6$ & $3,936.3$ & 195.9 & 254.9 & $6.4 \%$ \\
\hline 1982 & $3,166.0$ & $3,881.5$ & 196.0 & 240.3 & $0.2 \%$ \\
\hline 1983 & $3,405.7$ & $4,042.6$ & 225.7 & 267.9 & $6.6 \%$ \\
\hline 1984 & $3,772.2$ & $4,296.5$ & 258.3 & 294.2 & $6.8 \%$ \\
\hline 1985 & $4,010.3$ & $4,411.3$ & 272.4 & 299.6 & $6.8 \%$ \\
\hline 1986 & $4,235.0$ & $4,569.6$ & 285.0 & 307.5 & $6.7 \%$ \\
\hline 1987 & $4,515.6$ & $4,700.7$ & 295.6 & 307.7 & $6.5 \%$ \\
\hline 1988 & $4,873.7$ & $4,873.7$ & 6 & $c$ & 5 \\
\hline 1989 & $5,200.8$ & $4,961.6$ & c & c & : \\
\hline \multicolumn{6}{|c|}{ Average annual percentage change } \\
\hline $1970-89$ & $9.0 \%$ & $2.5 \%$ & $8.3 \%^{d}$ & $2.2 \%^{d}$ & \\
\hline 1982.89 & $7.3 \%$ & $3.6 \%$ & $8.6 \%$ & $5.1 \%{ }^{d}$ & \\
\hline
\end{tabular}

Souros:

1970-1986 data - U.S. Department of Commerce, Burcau of Census, Statistical Abstract of the United States 1988, p.410.

1987-1989 data - U.S. Department of Commerce, Bureau of Economic Analysis, Survey of Current Business, July, 1990.

Transportation Gross National Product includes motor vehicle and other transportation equipment manufacturing; railroad transportation; local and interurban passenger transit; trucking and warehousing; water transportation; transportation by air; pipelines, except natural gas; transportation services; and auto repairs, services and garages.

${ }^{b}$ Adjusted by the implicit GNP price deflator.

'Data are not available. The Burcau of Economic Analysis has delayed the release of the data in order to revise earlier estimates to incorporate several improvements.

${ }^{๑}$ Average annual percentage changes are for years 1970-87 and 1982-87.

(ORNL-6649 (Edition il of ORNL-5198, Jan. 1991)

$$
\text { I.B. }-5
$$


Appendix I

C. Emission

I.C. 


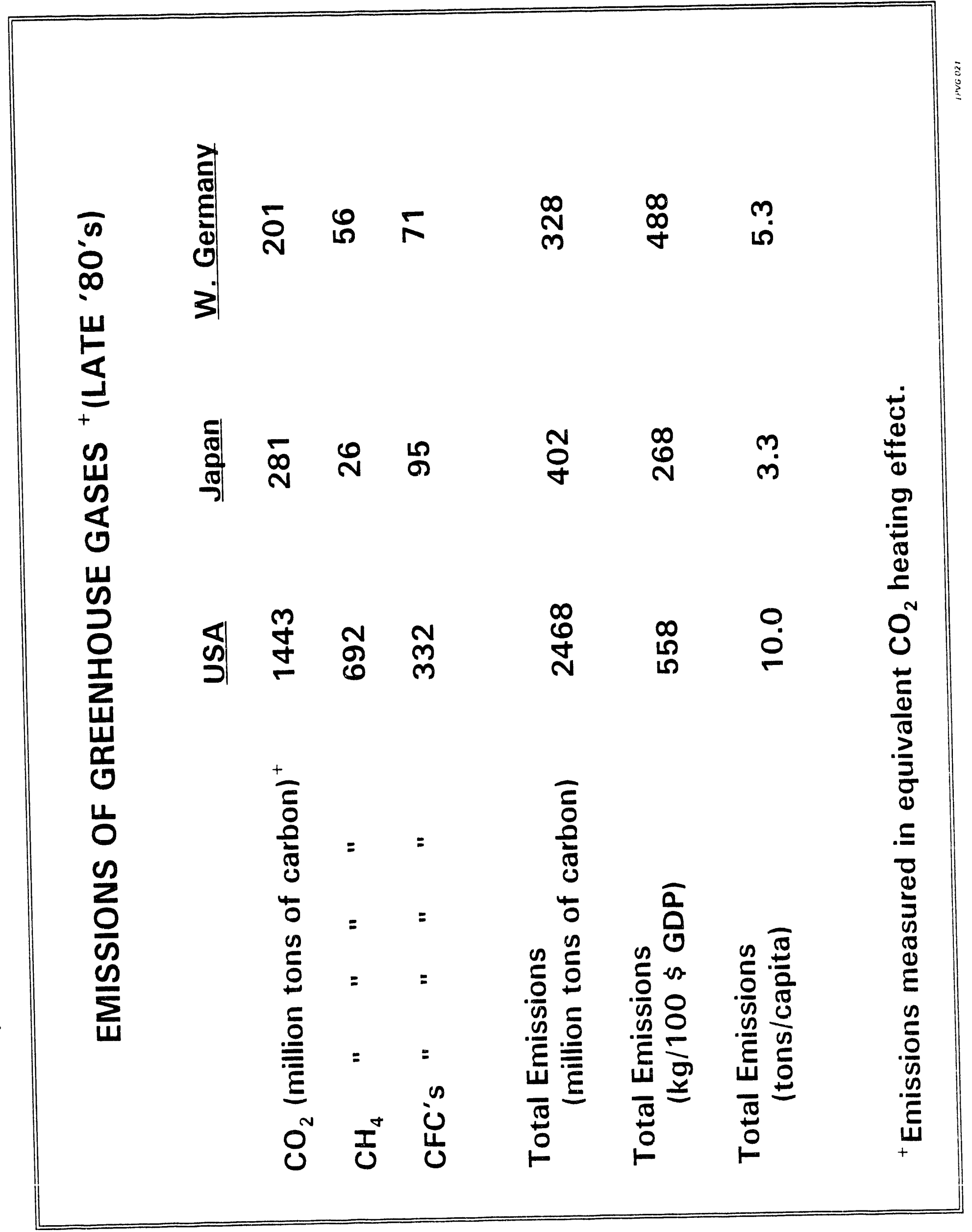




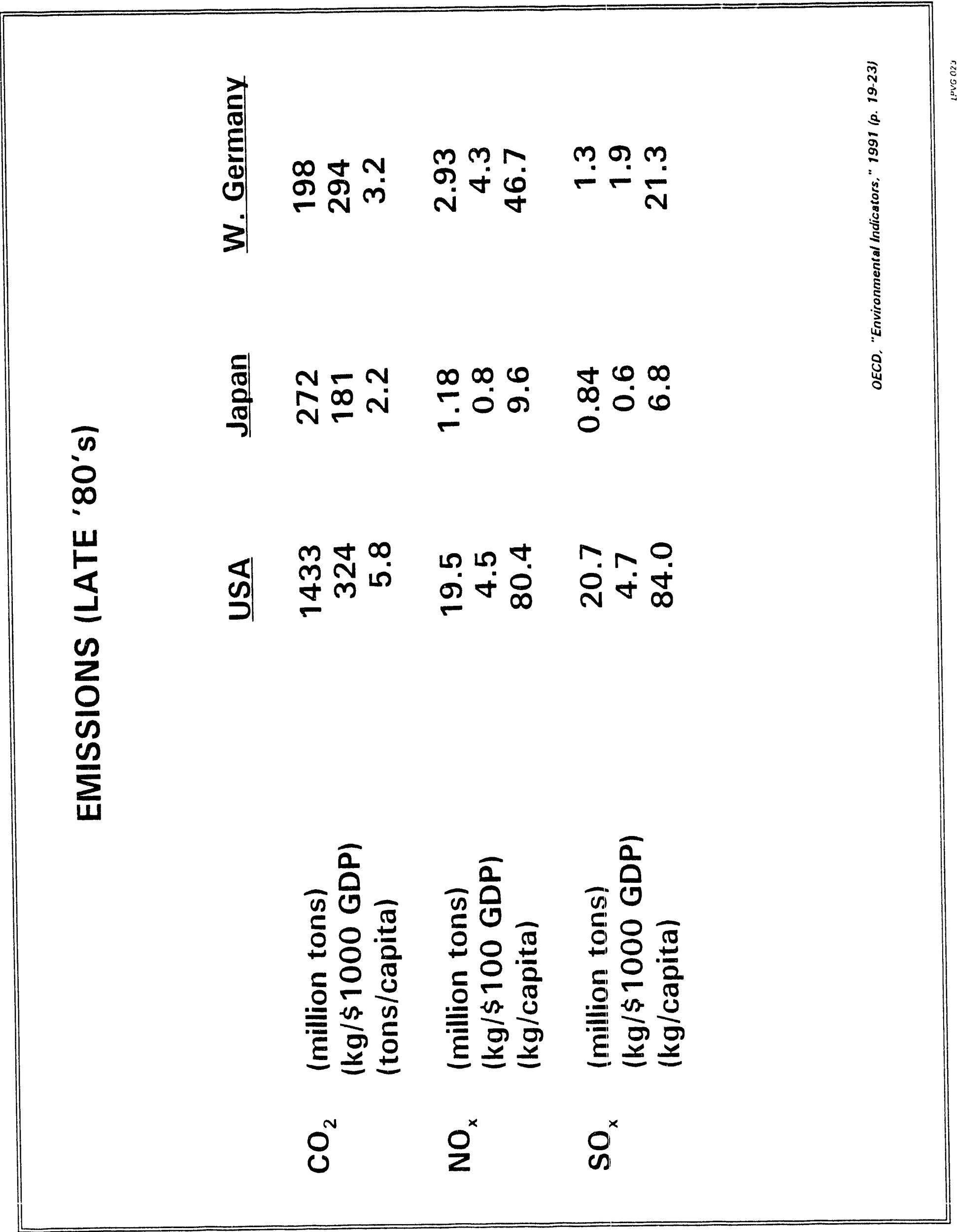




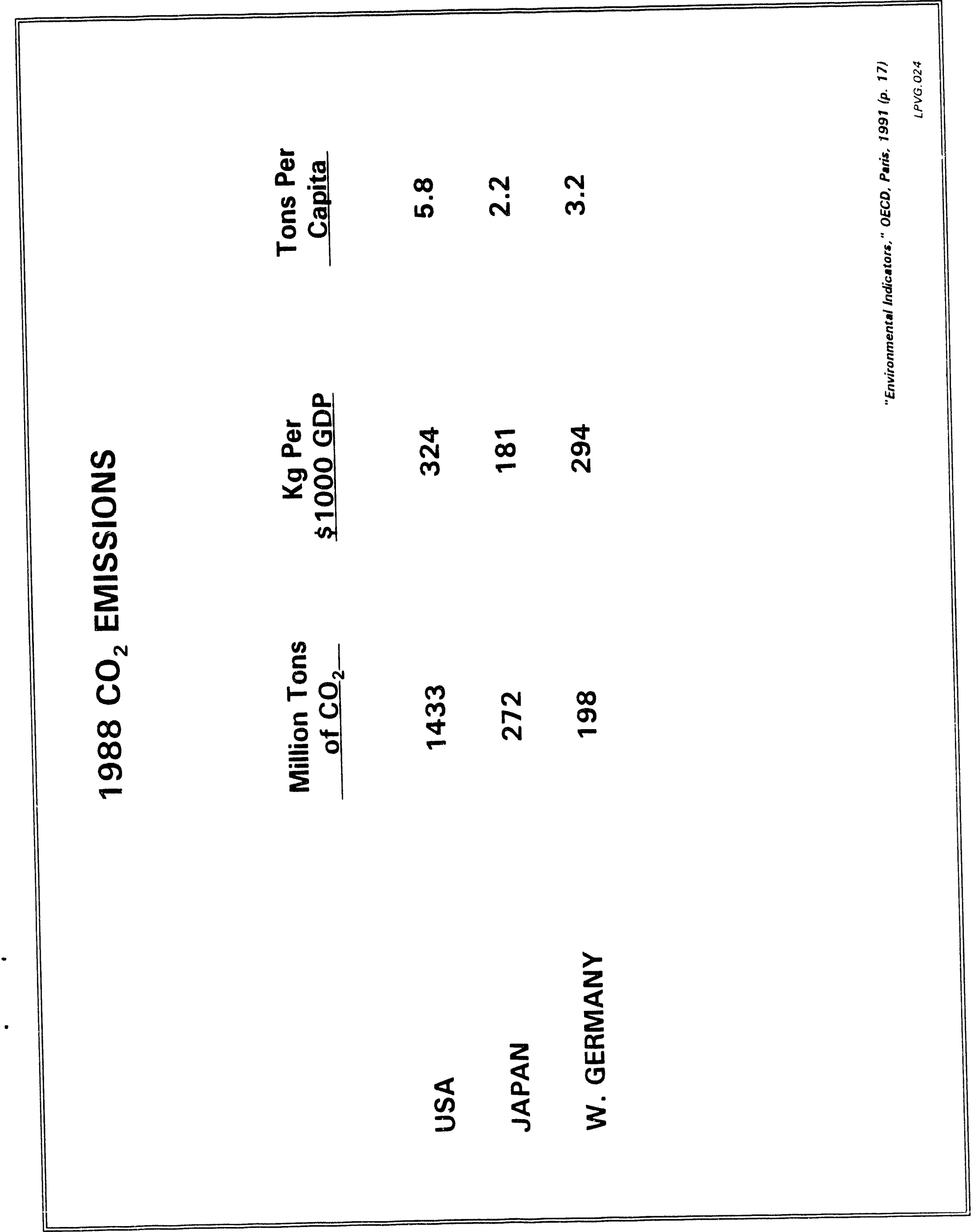

$$
\text { I. C } 0-3
$$




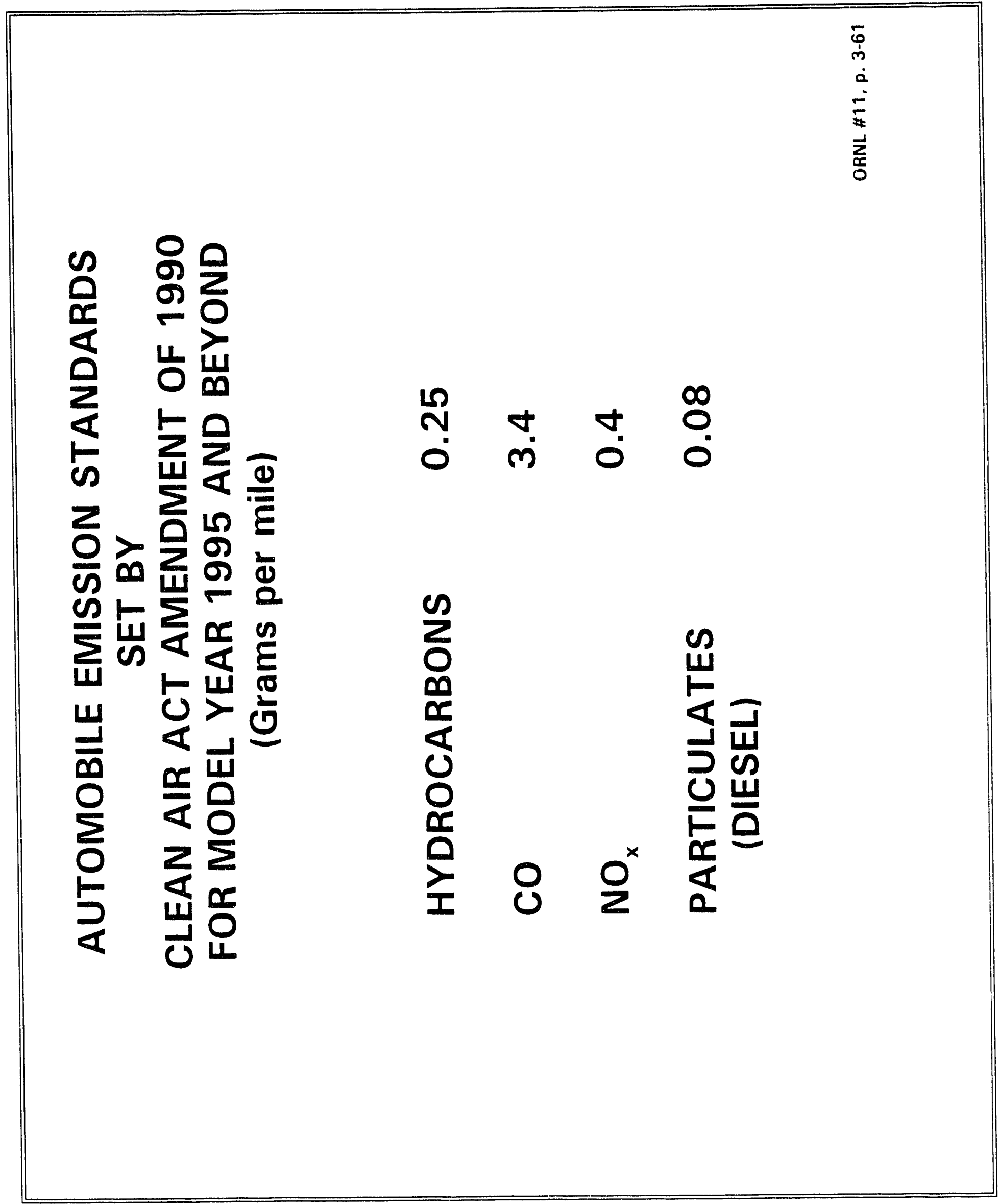




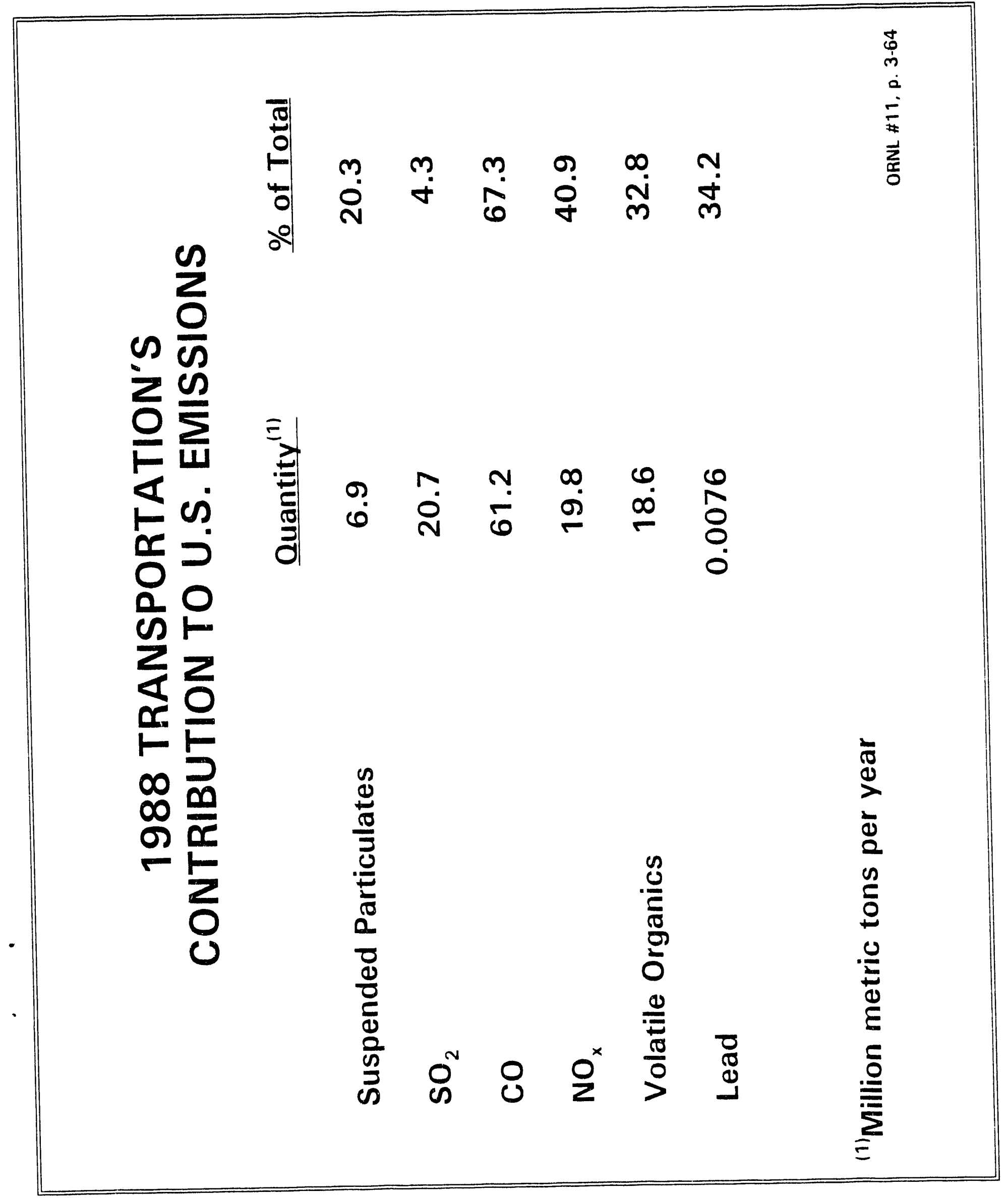


Appendix II

Energy and Environmental Technology:

The Transportation Sector

in the

National Workshop on Critical Technologies Research:

Opportunities for DOE (May 27-29, 1992)

Lawrence Berkeley Laboratory

Berkeley, CA 
CRITICAL TECHNOLOGIES RESEARCH: OPPORTUNITIES FOR DOE ENERGY \& ENVIRONMENT: TRANSPORTATION SECTOR

\section{SOCIETAL PROBLEMS}

- ENVIRONMENT \& HEALTH EFFECTS

- Emissions, including greenhouse gases

- Safety issues

- FOREIGN OIL DEPENDENCE/INEFFICIENT USE OF ENERGY

- URBAN CONGESTION/LOSS OF PRODUCTIVITY

- LOW ECONOMIC PRODUCTIVITY/JOBS CREATED FROM ENERGY INVESTMENT

- INTERMODAL INFRASTRUCTURE CREATION/MAINTENANCE

- OTHERS

- Public travel mode preferences

- Energy sources related to electric vehicle use

- New technologies impediments

- Lack of manufacturing research

- Loss of auto market share 
CRITICAL TECHNOLOGIES RESEARCH:

OPPORTUNITIES FOR DOE ENERGY \& ENVIRONMENT:

TRANSPORTATION SECTOR

INSTITUTIONAL BARRIERS

- INTERAGENCY COOPERATION - FEDERAL/STATE REGIONAL/NATIONAL LABS

- CRADA ISSUES/PROBLEMS

- POLICY ISSUES

- OIL TAXED TO REFLECT FULL SOCIETAL MARGINAL COST

- INFRASTRUCTURE MAINTENANCE SUBSIDIES/ ENERGY PRICE

- PRIORITY OF ENERGY EFFICIENCY VS ENVIRONMENTAL QUALITY/TRADE BALANCE ISSUES

- INTERMODAL CONNECTIVITY

- RAIL TRANSPORT INEFFICIENCIES

- IVHS ISSUES

- REDUCTION OF EXISTING RESEARCH MONIES

INTO MANUFACTURING RESEARCH 
CRITICAL TECHNOLOGIES RESEARCH: OPPORTUNITIES FOR DOE ENERGY \& ENVIRONMENT: TRANSPORTATION SECTOR

\section{RESEARCH NEEDS: \\ OPPORTUNITIES/TECHNOLOGIES}

- POLICY/INTEGRATED RESOURCE PLANNING

- ALTERNATE FUELS/HYBRID VEHICLES

- ADVANCED/LIGHTWEIGHT/NEW MATERIALS

- ADVANCED BATTERIES/ENERGY STORAGE

- ANALYTICAL MODELING OF TRANSPORT CHOICES

- MAGLEV RESEARCH

- ADVANCED ENGINE/COMBUSTION/FUEL RESEARCH

- EMISSIONS RESEARCH/CATALYST DEVELOPMENT

- BULLING TECHNOLOGIES APPLIED TO VEHCLES

- HIGH PERFORMANCE COMPUTING IN MANUFACTURING

- IVHS, SENSORS DEVELOPMENT, VEIICLE RECYCLING 


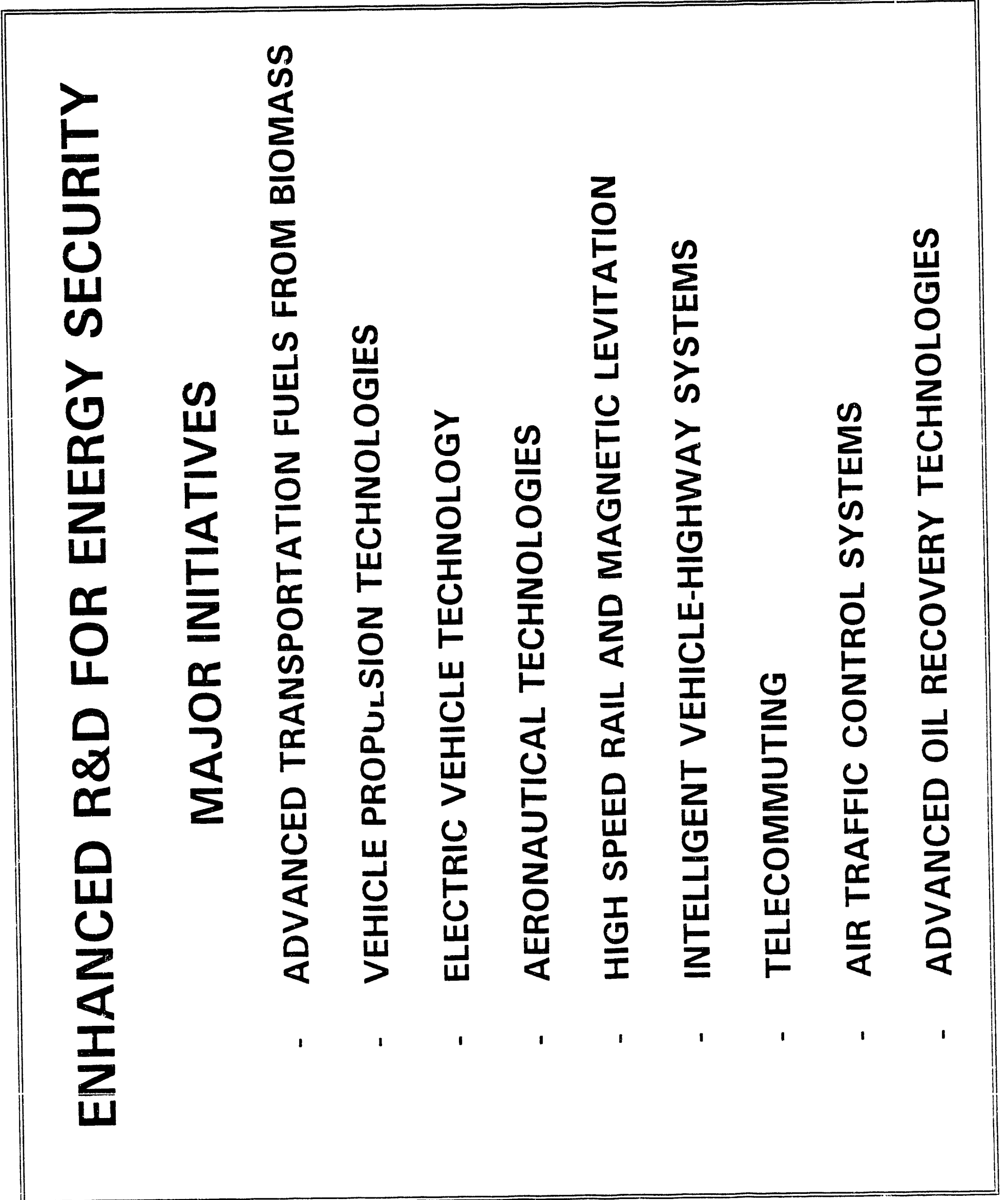


CRITICAL TECHNOLOGIES RESEARCH: OPPORTUNITIES FOR DOE ENERGY \& ENVIRONMENT: TRANSPORTATION SECTOR

\section{CURRENT CAPABILITIES AT NATIONAL LABS}

ANALYTICAL MODELING/FORECASTING

COMBUSTON RESEARCH

CORROSION RESEARCH

MAGLEV RESEARCH

ADVANCED/LIGHTWEIGHT MATERIALS

ADVANCED BATTERY CONSORTIUM/

FUEL CELLS/HYBRID VEHICLES

\section{ALTERNATE/MODIFIED FUELS AND} ENGINES

SENSORS

BUILDINGS TECHNOLOGY APPLICATIONS

CATALYSTS

MOBILE NATURAL GAS STORAGE

VEHICLE RECYCLING
ANL, BNL, ORNL, LBL, NREL, PNL, LANL, LLL

LANL, LBL, SNL

BNL

BNL, ANL

LANL, ORNL, ANL, LBL, SNL, NREL, BNL

NREL, ANL, LBL, SNL, ORNL. LANL

ANL, ORNL, NREL

LANL

LBL, NREL

LANL, NREL, BNL, LBL

BNL

ANL 


\section{RESEARCH OPPORTUNITIES}

Technology (R\&D

Policy, Systems Analysis, Modeling

Data Information Management

Advanced Materials

Hybrid Vehicles

Alternate Power Sources

Emissions Control/Catalysts, Sensors

Combustion

IVHS

Maglev

Non-Technology

Interagency Cooperation

Intermodal Integration

Lifestyle Changes

Policy Issues - Tradeoff Issues

- Efficiency/Environ. Quality

- Infrastructure Maint./Energy Price

- Energy Independence 
CRITICAL TECHINOLOGIES RESEARCH: OPPORTUNITIES FOR DOE ENERGY \& ENVIRONMENT: TRANSPORTATION SECTOR

RECOMMENDATIONS: TRANSPORTATION SECTOR

- deVelop an aCtion plan by CONVENING a WORKShop of NATIONAL LABORATORY EXPERTS AND WITH INDUSTRY PARTICIPATION TO FOCUS, PRIORITIZE, STREAMLINE AND COORDINATE CURRENT AND PROJECTED R\&D AT NATIONAL LABS.

- STREAMLINE AND COORDINATE PLANNING AND PROGRAM SPONSORSHIP FROM VARIOUS DOE OFFICES.

- DEVELOP A COMPREHENSIVE MODEL FOR TRUE COST ASSESSMENT OF TOTAL FUEL-CYCLES AND TRANSPORTATION SYSTEMS ALTERNATIVES AND TRADEOFFS. "TOTAL COST" SHOULD INCLUDE COSTS OF HEALTH, ENVIRONMENT, SAFETY, RETRAINING SUBSIDIES AND OTHER EXTERNALITIES. INTERCOMPARISONS SHOULD BE MADE USING THE NES CRITERIA, i.e., ENVIRONMENT, ECONOMY AND NATIONAL SECURITY.

- GIVE PRIORITY TO MEASURES FOR MEANINGFUL NATIONAL LABS/INDUSTRY COOPERATION. TWO CONCRETE STEPS:

A) TWO-WEEK TURNAROUND TIME FOR CRADAs,

B) DIRECT 10\% OF NATIONAL LABS' BUDGET TOWARDS ENABLING TECHNOLOGY FOR INDUSTRY.

C) ARRANGE FOR SABBATICALS AND OTHER PERSONNEL EXCHANGE PRACTICES BETWEEN NATIONAL LABS AND INDUSTRY.

- CREATE AN INTERAGENCY COMMITTEE PATTERNED ALONG TIE CEES (Committee on Earth and Environmental Sciences) TO SET POLICY AND PROVIDE GUIDANCE FOR TRANSPORTATION R\&D. 


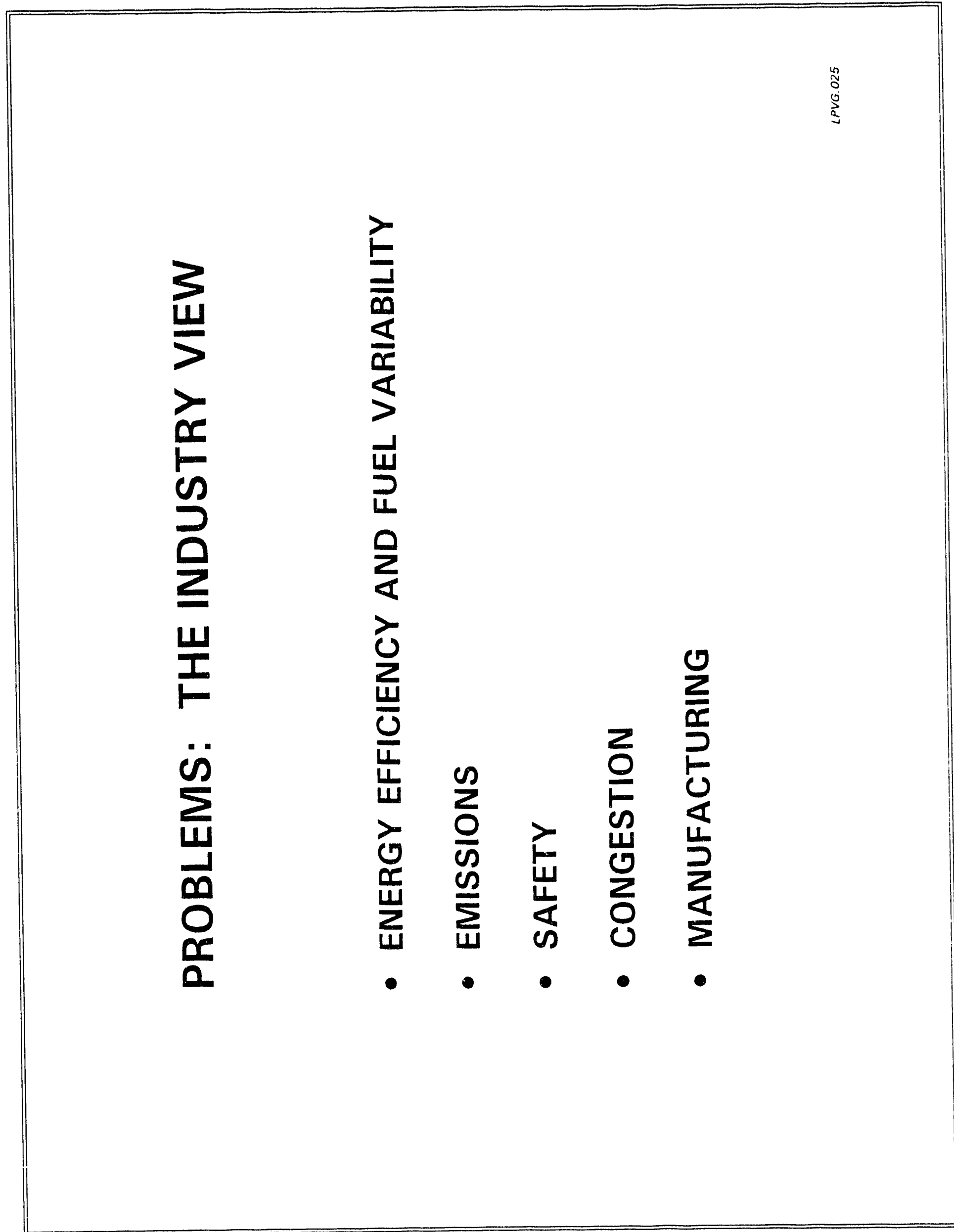

I I . -8 


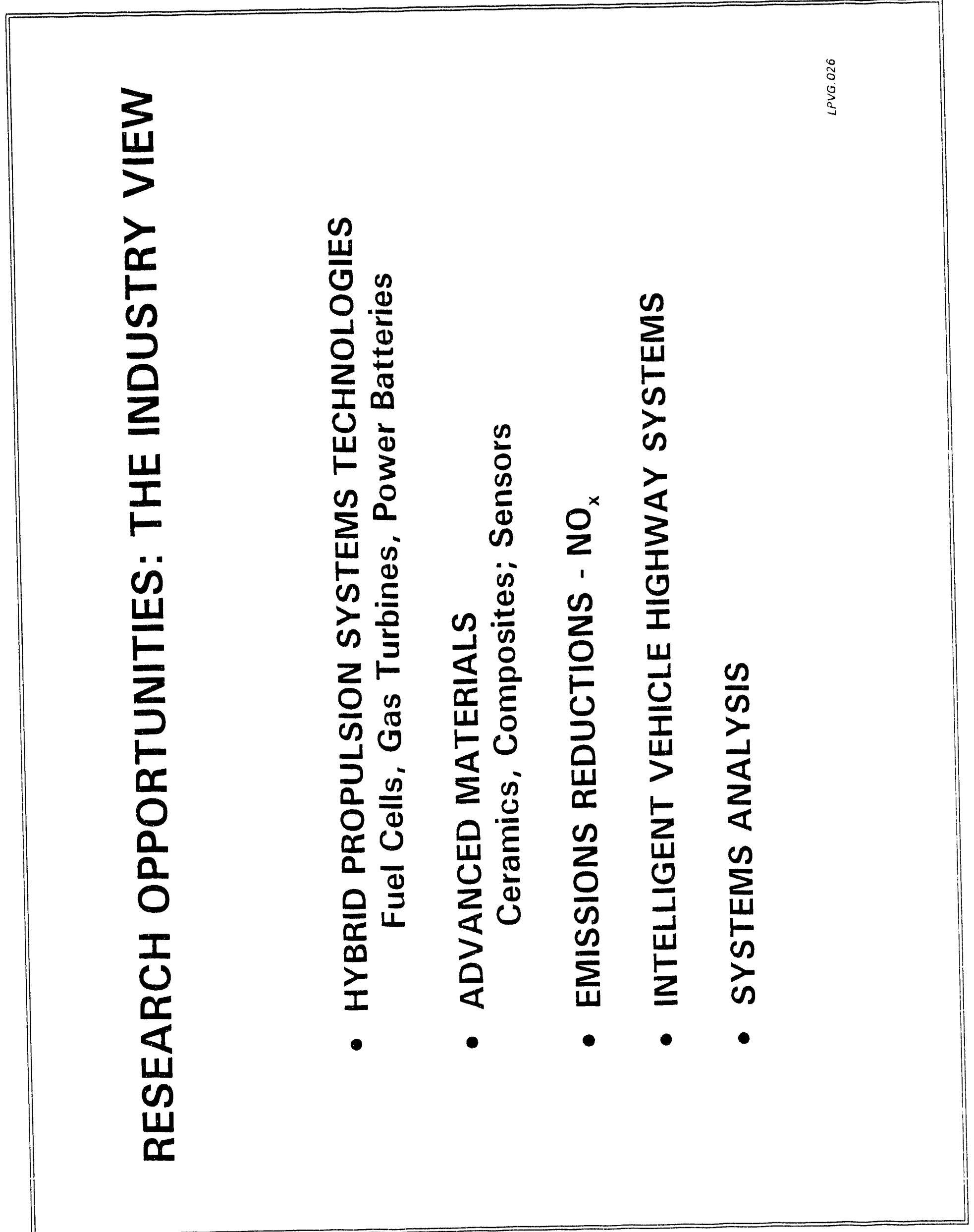




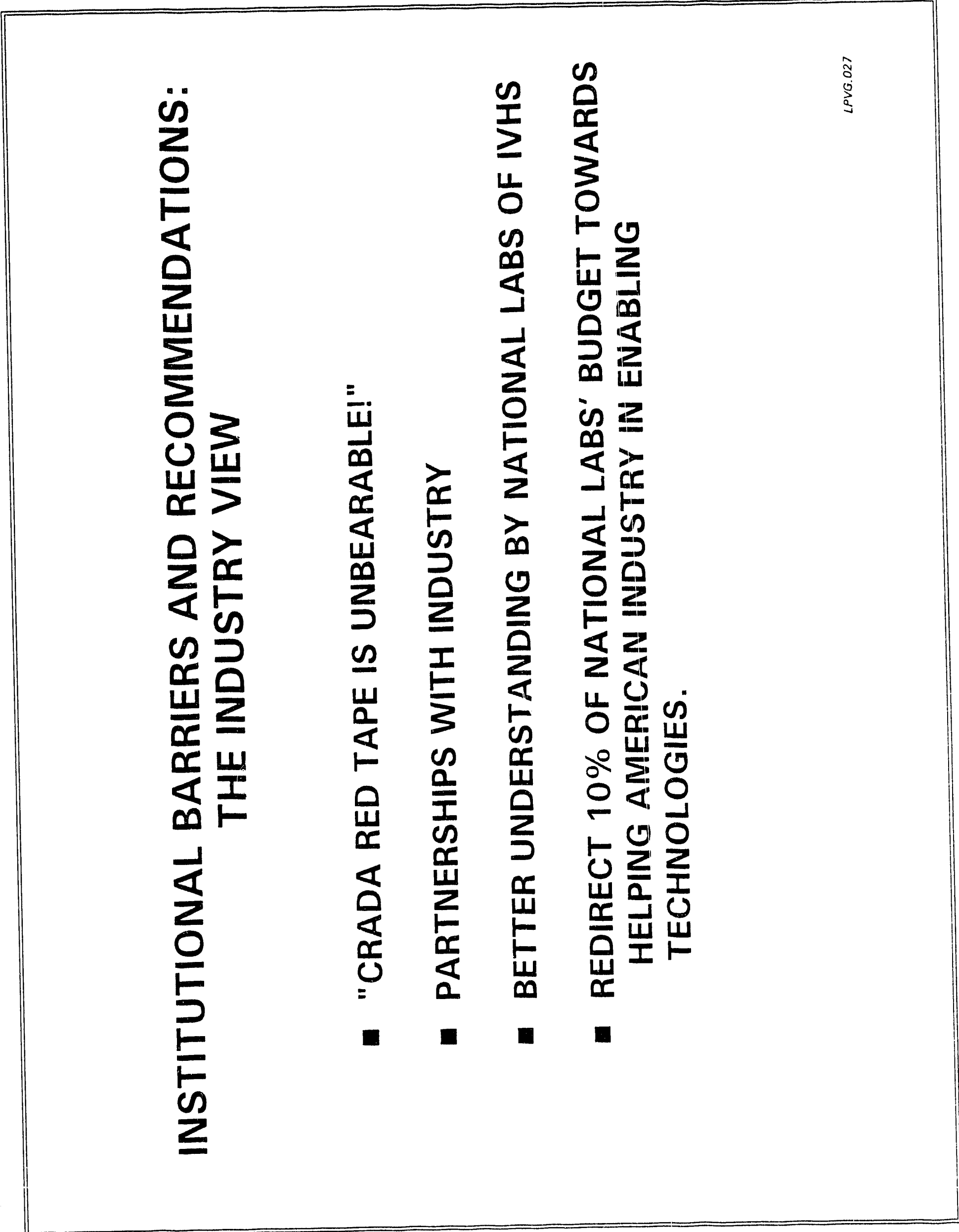



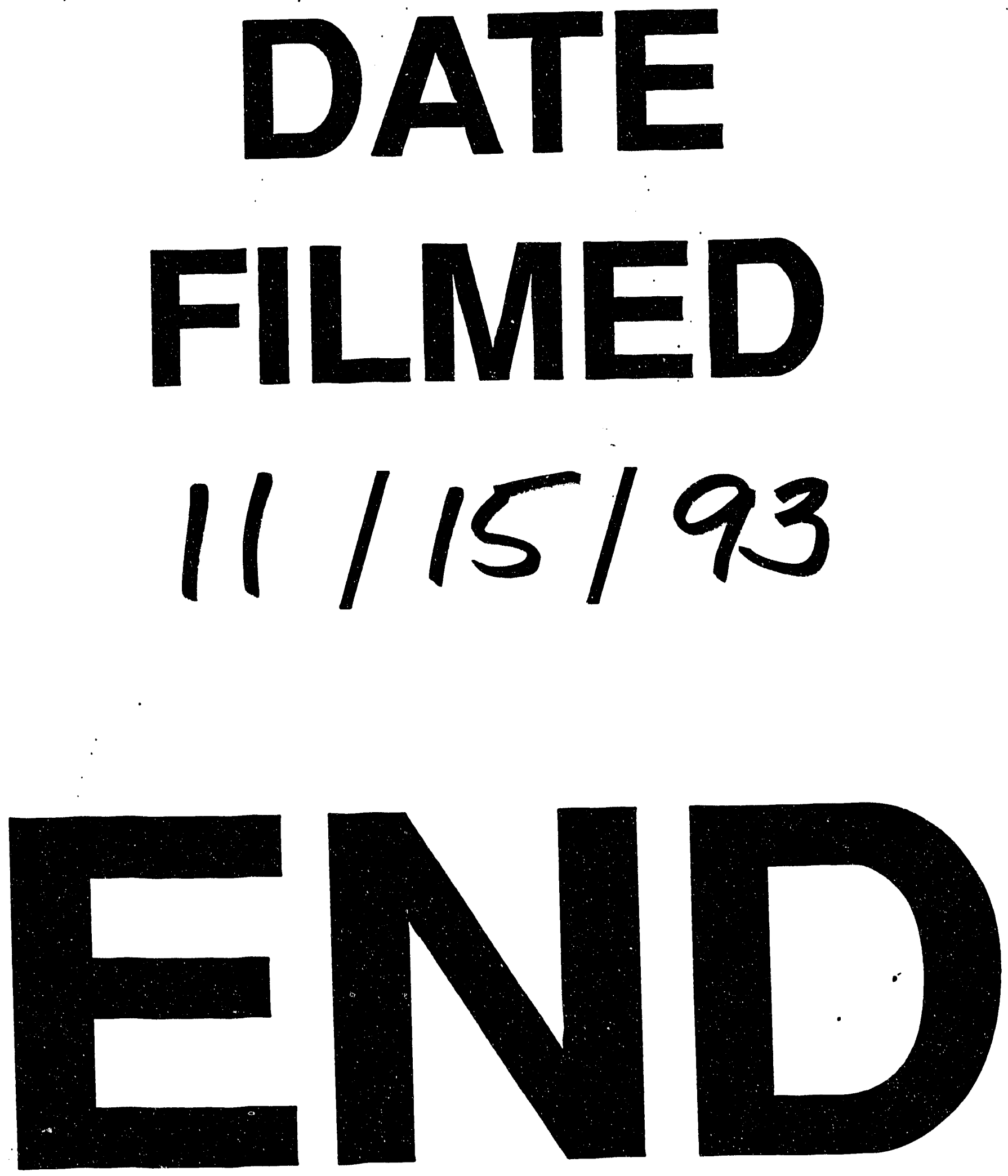
